\title{
Healthy eating interventions delivered in the family home: a systematic review
}

\section{Article}

\section{Accepted Version}

Creative Commons: Attribution-Noncommercial-No Derivative Works 4.0

Snuggs, S. ORCID: https://orcid.org/0000-0001-5191-9517, Houston-Price, C. and Harvey, K. (2019) Healthy eating interventions delivered in the family home: a systematic review. Appetite, 140. pp. 114-133. ISSN 0195-6663 doi: https://doi.org/10.1016/j.appet.2019.05.014 Available at https://centaur.reading.ac.uk/83569/

It is advisable to refer to the publisher's version if you intend to cite from the work. See Guidance on citing.

To link to this article DOI: http://dx.doi.org/10.1016/j.appet.2019.05.014

Publisher: Elsevier

All outputs in CentAUR are protected by Intellectual Property Rights law, including copyright law. Copyright and IPR is retained by the creators or other copyright holders. Terms and conditions for use of this material are defined in the End User Agreement.

\section{www.reading.ac.uk/centaur}

\section{CentAUR}

Central Archive at the University of Reading 
Reading's research outputs online 
Healthy eating interventions delivered in the family home:

\section{A systematic review}

Sarah Snuggs ${ }^{1}$, Carmel Houston-Price ${ }^{1}$ and Kate Harvey*1

${ }^{1}$ School of Psychology and Clinical Language Sciences

University of Reading, RG6 7BE

*Corresponding author 


\section{Introduction}

Food preferences and eating behaviours develop early in life (Savage, Fisher, \& Birch, 2007). Healthy eating in the first five years is linked to current and future health (Branca, Piwoz, Schultink, \& Sullivan, 2015; Ogden, 2012; Rasmussen et al., 2006), and both dietary variety seeking (Nicklaus, Boggio, Chabanet, \& Issanchou, 2005) and untreated overweight/obesity (Vivier \& Tompkins, 2008) are likely to track from childhood into adulthood. Thus, it is important to address unhealthy eating as early as possible.

Healthy eating refers to the consumption of a wide variety of foods in the correct proportions to achieve and maintain a healthy body weight (National Health Service (NHS), 2014). A balance of fruit, vegetables, complex carbohydrates and protein is considered beneficial (NHS, 2015), while high intake of processed food, sugar and/or salt reflects a substandard diet, and both over- and undereating are considered unhealthy behaviours (World Health Organisation (WHO), 2015). Unhealthy diet in children is considered to be a widespread problem (WHO, 2015). Across the economically developed world, between a quarter and a third of children are typically overweight or obese (NHS, 2017; Rodd \& Sharma, 2016; State of Obesity, 2017). Children also consume fewer fruit and vegetable (FV) portions than the recommended daily guidance (Dennison, Rockwell, \& Baker, 1998; Kim et al., 2014) and both obese and non-obese children are thought to consume inadequate nutrients (Gillis \& Gillis, 2005). Many national governments have therefore introduced campaigns to address children's food choices, many emphasising the need for balance and variety in children's diets (e.g. Change4Life, 2015; Government of Canada, 2018; USDA, 2018).

A key focus for such interventions is what young people eat at home. In their first few, formative, years, and even once they have started school, children eat most of their meals in the home environment (Poti \& Popkin, 2011). Inevitably, parents play an important role in 
shaping children's food choices, eating behaviours and habits. Evidence indicates that eating behaviour interventions for children should target parents as the principal agents of change (Golan, 2006) (although adolescents may achieve greater dietary change when treated directly; see McLean, Griffin, Toney, \& Hardeman, 2003). This systematic review evaluates the evidence relating to interventions delivered at home that seek to support healthy eating in children who are both overweight and of a healthy weight.

There are a number of well-established home environment correlates to healthy eating and willingness to try new foods in children (Blanchette \& Brug, 2005; Pearson, Ball, \& Crawford, 2012). Children are more likely to consume and enjoy new foods if they are exposed to them repeatedly (Anzman-Frasca, Savage, Marini, Fisher, \& Birch, 2012; Mitchell, Farrow, Haycraft, \& Meyer, 2013; Patrick \& Nicklas, 2005). This is thought to be due to learned safety of exposed foods (Kalat \& Rozin, 1973) or exposure effects leading to positive attitudes to more familiar foods (Zajonc, 1968). Parents' modelling of healthy food consumption also influences children's food choices, both through social learning processes such as imitation and through greater exposure to foods parents are eating (Dickens \& Ogden, 2014; Savage, et al., 2007). For children to consume a food, it must be both available (in the home and offered to the child) and accessible (in a format easy to reach and consume) (Patrick \& Nicklas, 2005). Exposure, modelling, availability and accessibility of healthy foods are consistently found to be strong predictors of children's healthy eating (Pearson, et al., 2012). In addition, children's and adolescents' nutritional health is associated with the frequency of shared family meals (Dwyer, Oh, Patrick, \& Hennessy, 2015), which is thought to be a protective factor against obesity and, possibly, disordered eating (Ackard and Neumark-Sztainer, 2001; Berge, Loth, Hanson, Croll-Lampert, \& Neumark-Sztainer, 2012). Shared family meals are more likely to be home-cooked (rather than 'ready-made') and nutritious (Gillman et al., 2000), and provide parents with more opportunity to model healthy 
eating. Social learning may partly explain the link between family meals and positive eating habits.

Some parents struggle to implement positive feeding practices, however (Carruth \& Skinner, 2000; Shloim, Edelson, Martin, \& Hetherington, 2015), even when informed about strategies to encourage healthy eating (Lindsay, Sussner, Greaney, \& Peterson, 2011). Parents cite time, budget and children's food preferences as interfering with their ability to follow relevant advice (Fulkerson et al., 2011). Interventions have been developed to support parents' behaviours and strategies around feeding children (both normal weight and overweight/obese) (Campbell \& Hesketh, 2007; Knowlden \& Sharma, 2012; Ling, Robbins, \& Wen, 2016; Van Lippevelde et al., 2012), typically delivered through group or individual meetings held in schools (Evans, Christian, Cleghorn, Greenwood, \& Cade, 2012; Mikkelsen, Husby, Skov, \& Perez-Cueto, 2014) or community venues (Bleich, Segal, Wu, Wilson, \& Wang, 2013). However, parents cite time, location and childcare considerations as barriers to participating in such eating behaviour interventions (Alff et al., 2012; Virudachalam et al., 2016).

To be effective, family eating interventions must be both practical and accessible for parents. Until recently, few interventions met these criteria; the majority were expensive and impractical to deliver on a large scale (Rudolf, 2012). For example, a Cochrane review conducted in 2012 (Wolfenden et al., 2012) identified only two home visit-based interventions that might be effective in increasing fruit and vegetable consumption in preschool children. However, in recent years, more interventions have been delivered within the family home, which reduces the barriers to participation for parents; advances in technology also permit the development of cheaper, more accessible, health behaviour interventions (WHO, 2017). Many of these draw on Social Cognitive Theory (SCT, Bandura, 1986) which 
attempts to change behaviour by addressing social cognitions. In the context of healthy eating, this involves addressing expectancies such as the health consequences of eating specific foods or incentives, for example, how individuals might feel after eating particular foods. For example, the Health Belief Model (Becker, 1974) has been used to predict healthy eating amongst various populations (Deshpande, Basil \& Basil, 2009) while the Theory of Planned Behaviour (Ajzen, 1991) has been used to address the intention-behaviour gap (Sheeran \& Webb, 2016) through manipulating parents' implementation intentions in relation to their children's sugar intake (Beale \& Manstead, 1991).

This current review considers the full literature that has addressed the question what is effective in changing eating behaviours in the family home? Given the broad implications of unhealthy eating in children, the review will include obesity prevention studies, obesity reduction studies and healthy eating studies in normal weight populations. It seeks to systematically review all intervention studies that have set out to change children's or families' eating behaviours and that are delivered exclusively to parents, children or families in the home environment and, in doing so, to address two questions:

(1) What intervention studies have been conducted to try to enhance healthy family eating behaviours within the family home? Outcomes considered include both changes in child health (e.g. adiposity, weight) and other positive features of family mealtimes (e.g. family mealtime frequency, positive feeding practices).

(2) What characteristics do successful interventions exhibit in relation to both their theoretical basis and more practical aspects of their design and implementation?

\section{Method}

The review protocol was registered with Prospero, the international prospective register of 
systematic reviews (https://www.crd.york.ac.uk/prospero/) on $5^{\text {th }}$ July 2016 , with a revision on $17^{\text {th }}$ February 2017 (registration number PROSPERO 2016:CRD42016042387).

\section{Search strategy}

A search was conducted in three electronic databases (Medline, Web of Science, The Cochrane Library) for articles published from 1980 to the present day on $12^{\text {th }}$ May 2016, and repeated on $22^{\text {nd }}$ January 2018 to update the results. The following search terms were used:

(1) Home*/house*/famil*/child*/toddler/pre-school*/preschool*/adolescen*/parent*

AND

(2) Eat*/feeding practice(s)/meal*

AND

(3) Intervention/prevention/program*/randomised controlled trial/randomized controlled trial/RCT/qualitative/course

Forward and backward citation searching, and additional hand-searching were also conducted. Reports outside academic peer-reviewed publications were not included.

PRISMA guidelines and checklist were complied with throughout (Moher, Liberati, Tetzlaff, Altman, \& The, 2009).

\section{Inclusion/exclusion criteria}

Step 1: Initial criteria to determine whether articles would be considered were: 1) English language; 2) human participants; 3) peer-reviewed journal publication.

Step 2: For articles that met these initial criteria, one researcher (SS) screened the titles and abstracts for inclusion using the following criteria: 
1) relevance (i.e. titles were excluded if the topic was unequivocally irrelevant. Examples of irrelevant topics included smoking cessation, Alzheimer's disease and alcohol abuse);

2) home-delivered intervention (studies involving visits to sites other than the family home for data collection purposes were included if all aspects of the intervention were delivered within the family home; interventions intended to be delivered at home but that could be accessed elsewhere (e.g. through a mobile device, or if visit locations were rearranged for convenience) were included);

3) focus on eating (however, studies were excluded if the focus was on condition-specific eating (e.g. autism, cerebral palsy), eating disorders or malnutrition in developing countries);

4) randomised controlled trial/ case-controlled trial/other controlled design/qualitative evaluation of intervention (reviews and meta-analyses were not included but were examined for relevant studies);

5) families had children aged $>6$ mo and $<16$ yo (participants could be children and/or parents/ carers; interventions were included if they were initiated before the child reached 6 mo but continued beyond this age and were focused on eating, rather than breast-feeding);

6) health-related outcome measure (e.g. dietary intake, BMI, parental feeding practices);

7) outcome data are published.

Five research assistants 'second-coded' all articles using the same criteria. All articles included by at least one coder underwent full text screening (step 3), to double check that criteria were met. Any article with unclear inclusion status at step 3 was considered by a third researcher $(\mathrm{KH})$. Where appropriate, study authors were contacted to clarify methodological details. See figure 1 for flow diagram of these steps. 
Figure 1: Study selection process

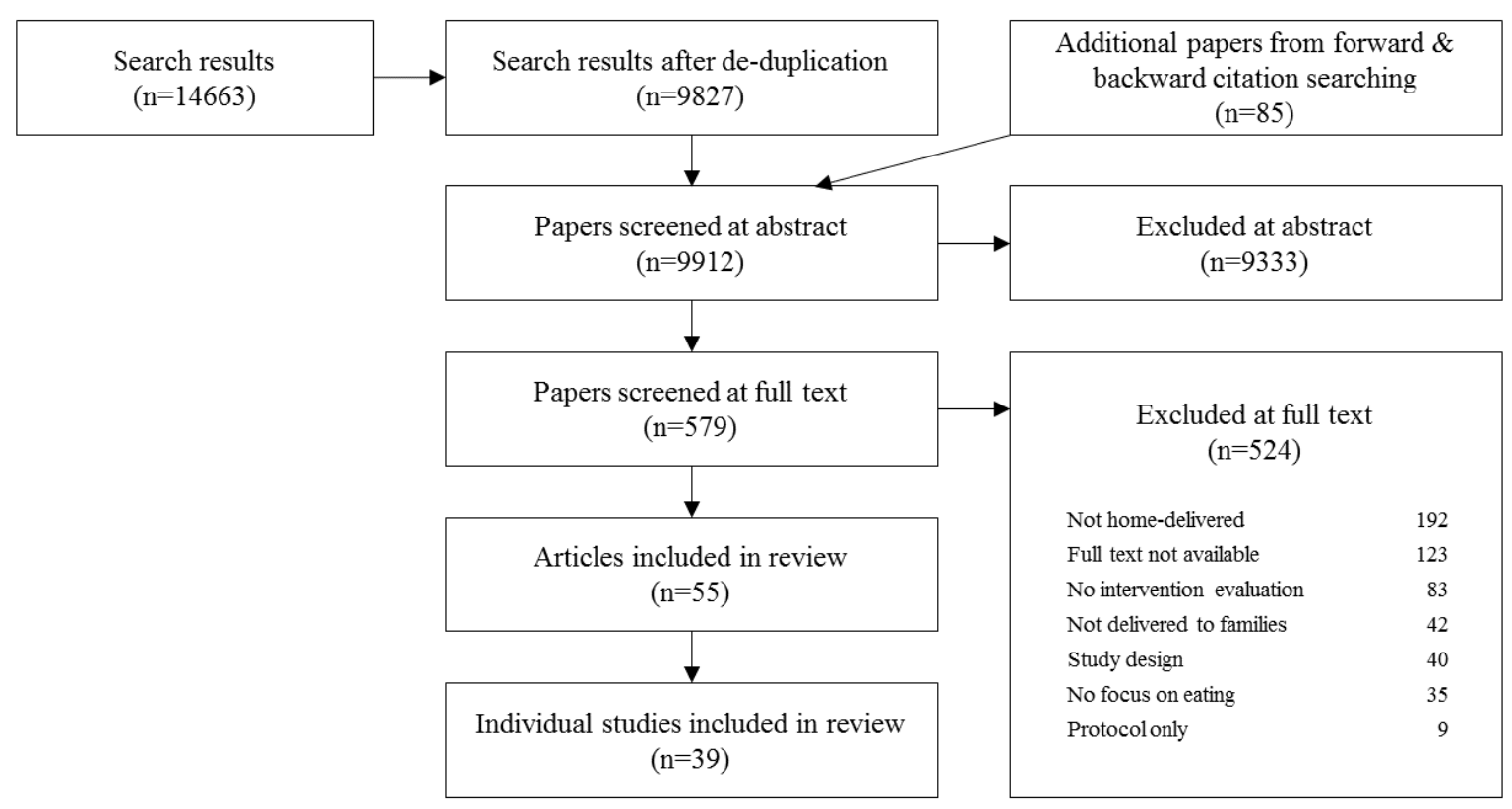

\section{Quality appraisal}

The quality appraisal considered criteria laid out by the Centre for Reviews and

Dissemination (CRD) (CRD, 2009), as follows: 1) Appropriateness of study design to research objective; 2) Risk of bias; 3) Choice of outcome measure; 4) Statistical issues; 5)

Quality of reporting; 6) Quality of the intervention; 7) Generalisability. The CRD recognises that elements of quality appraisal can be subjective and does not always recommend the use of checklists or scales to allocate quality scores (CRD, 2009 p.33-44). Thus, the above criteria were considered when evaluating studies but studies were not given quality ratings. Instead, studies were weighted equally and quality assessment is described in the narrative.

\section{Data synthesis}

A narrative summary technique was used to describe findings. Meta-analysis was not used as intervention formats, outcome measures and times of follow-ups varied widely between studies. 


\section{Results}

The search strategy yielded 9827 unique titles, 9774 of which were excluded. Fifty-five articles were included in the systematic review, representing 39 unique studies (some studies were reported in more than one paper) (Figure 1).

In all but three studies, participants were randomised or cluster-randomised to one or more Intervention Groups (IG) or to a Control or Comparator Group (CG). One of the remaining studies included a non-randomly allocated comparison group; two studies incorporated control through within-subjects designs. Three studies identified as pilot randomised trials.

A summary of the characteristics of included studies is provided in Table 1. Included studies were conducted in the United States (US, n=15), United Kingdom (UK, n=9), Australia $(n=4)$, US/Mexico border $(n=2)$, Germany $(n=2)$, US and Canada $(n=1)$, Brazil, Hong Kong, Italy, the Netherlands, New Zealand and Sweden ( $\mathrm{n}=1$ in each case). Where studies did not state the setting, it was assumed that this was the authors' country of residence. 
Table 1. Intervention characteristics

\begin{tabular}{|c|c|c|c|c|c|c|}
\hline Study type (n) & $\begin{array}{l}\text { Formative } \\
\text { work/inter } \\
\text { vention } \\
\text { developme } \\
\text { nt } \\
\text { described } \\
\text { or pilot } \\
\text { work } \\
\text { referenced: } \\
\text { n }(\%) \\
\end{array}$ & $\begin{array}{l}\text { Participant or } \\
\text { process } \\
\text { evaluation } \\
\text { reported (or } \\
\text { referenced): } \\
\text { n }(\%)\end{array}$ & $\begin{array}{l}\text { Retention } \\
\text { rate range* }\end{array}$ & $\begin{array}{l}\text { Financial } \\
\text { incentives } \\
\text { used to } \\
\text { engage in } \\
\text { study: } \\
\text { n }(\%)\end{array}$ & $\begin{array}{l}\text { Effect sizes } \\
\text { reported in } \\
\text { conventional } \\
\text { format: } \\
\mathrm{n}(\%)\end{array}$ & $\begin{array}{l}\text { Intention to } \\
\text { treat } \\
\text { analysis } \\
\text { employed } \\
\text { n }(\%)\end{array}$ \\
\hline Home visit (15) & $9(60 \%)$ & $5(33 \%)$ & $55 \%-100 \%$ & $3(20 \%)$ & $3(20 \%)$ & $6(43 \%)$ \\
\hline Telephone (3) & $2(66) \%$ & $2(33 \%)$ & $55 \%-86 \%$ & $1(33 \%)$ & 0 & $2(66 \%)$ \\
\hline Printed materials (9) & $2(22 \%)$ & $4(44 \%)$ & $38 \%-100 \%$ & 0 & $4(44 \%)$ & $3(33 \%)$ \\
\hline Video game (4) & $4(100 \%)$ & $3(75 \%)$ & $87 \%-97 \%$ & $1(25 \%)$ & $1(25 \%)$ & $2(66 \%)$ \\
\hline mHealth**(7) & $6(86 \%)$ & $4(57 \%)$ & $35 \%-91 \%$ & $3(43 \%)$ & $3(43 \%)$ & $1(14 \%)$ \\
\hline Other (1) & $1(100 \%)$ & 0 & $100 \%$ & 0 & 0 & $\mathrm{n} / \mathrm{a}$ \\
\hline All studies & $24(61 \%)$ & $18(46 \%)$ & $35 \%-100 \%$ & $8(21 \%)$ & $11(29 \%)$ & $14(39 \%)$ \\
\hline
\end{tabular}

*For studies with insufficient information, no retention rate has been reported

**mHealth refers to health interventions delivered through wireless technology (e.g. mobile phones) 
The majority of studies targeted families with children of normal weight; one study targeted picky eaters. Just over half reported the theory or evidence base behind the intervention, with Social Cognitive Theory as the most commonly cited theory. A similar number reported evidence of formative work around the development of the intervention, although fewer than half reported any element of participant or process evaluation. Most studies did not report using intention to treat (ITT) analyses (i.e. including all randomised participants in analyses, regardless of completion status). Follow-up periods varied, from no follow up (i.e. immediate post-intervention data collection only) to four years.

Only eight studies reported effect sizes in a conventional format (e.g. Cohen's $d$ ); a further seven discussed the size of the effects found (e.g. increases in vegetable intake in terms of portions). No study reported a cost-effectiveness analysis, although one collected cost data for future analysis. No study blinded participants to condition; several explained that this was procedurally impossible, given the behavioural nature of the interventions.

The interventions discussed in the following section are divided into those that are persondelivered (face-to-face or telephone) versus information/technology-delivered (printed materials, video games and mHealth) and further categorised by intervention type and setting. Studies are first summarised and evaluated in detail, after which the evidence is synthesised and conclusions drawn.

\section{PERSON-DELIVERED INTERVENTIONS}

\section{Home visits}

Fifteen of the 39 identified studies involved home visits. Table 1 summarises the characteristics of these studies. Table 2 provides further details of the individual studies. Given that the cost, practicality and resources required by such interventions vary widely 
depending on who undertakes the home visits, studies are divided into interventions delivered by healthcare professionals, peer supporters and researchers. 
Table 2: Home visit study characteristics

\begin{tabular}{|c|c|c|c|c|c|c|c|c|c|c|}
\hline \multicolumn{10}{|c|}{ Home visit intervention studies } & \multirow[b]{2}{*}{$\begin{array}{l}\text { Theoretical } \\
\text { framework }\end{array}$} \\
\hline Authors & Year & $\begin{array}{l}\text { Home } \\
\text { visitors }\end{array}$ & $\begin{array}{l}\text { Other } \\
\text { resources }\end{array}$ & $\begin{array}{l}\mathbf{N} \text { of visits } \\
\text { (intervention } \\
\text { length) }\end{array}$ & $\begin{array}{l}\text { Length } \\
\text { of } \\
\text { visits }\end{array}$ & $\begin{array}{l}\text { Target of } \\
\text { intervention }\end{array}$ & $\begin{array}{l}\text { Primary } \\
\text { outcome } \\
\text { (measure)* }\end{array}$ & $\begin{array}{l}\text { Statistically } \\
\text { significant difference } \\
\text { shown on primary } \\
\text { outcome immediate } \\
\text { IPI? }\end{array}$ & $\begin{array}{l}\text { Statistically } \\
\text { significant } \\
\text { difference shown at } \\
\text { LTFU? (LTFU } \\
\text { period) }\end{array}$ & \\
\hline Corsini et al. & 2013 & $\begin{array}{l}\text { Market } \\
\text { researchers }\end{array}$ & $\begin{array}{l}\text { Booklet } \\
\text { with } \\
\text { guidance } \\
\text { around } \\
\text { refusal to } \\
\text { taste }\end{array}$ & $\begin{array}{l}1 \\
\text { (followed by } \\
2 \text { wk } \\
\text { intervention } \\
\text { period) }\end{array}$ & NR & $\begin{array}{l}\text { Liking \& } \\
\text { intake of } \\
\text { previously } \\
\text { disliked } \\
\text { vegetable }\end{array}$ & $\begin{array}{l}\text { Vegetable liking } \\
\& \text { consumption } \\
\text { (5-point scale \& } \\
\text { weight of leftover } \\
\text { vegetable) }\end{array}$ & $\begin{array}{l}\text { Liking increased for } \\
\text { exposure \& exposure }+ \\
\text { reward groups } \\
(\mathrm{p}=0.002 \& \mathrm{p}<0.001) \\
\text { but no significant } \\
\text { difference between CG } \\
\& \text { IGs for consumption }\end{array}$ & $\begin{array}{l}\text { No further change in } \\
\text { liking at } 4 \mathrm{wks} \text { or } 3 \mathrm{~m} \\
\text { ( } \text { value not reported } \\
\text { for between group } \\
\text { differences). } \\
\text { Consumption } \\
\text { increased in exposure } \\
+ \text { reward and CG } \\
\text { groups ( }=0.013 \& \\
\text { p }<0.001) \text { but not } \\
\text { exposure only. }(3 \mathrm{~m})\end{array}$ & Not stated \\
\hline Cravener et al. & 2015 & $\begin{array}{l}\text { Researcher } \\
\mathrm{s}\end{array}$ & $\begin{array}{l}\text { Vegetable } \\
\text { packages, } \\
\text { granola } \\
\text { bars, } \\
\text { sticker } \\
\text { incentives }\end{array}$ & $\begin{array}{l}4 \\
(4 \mathrm{wks})\end{array}$ & NR & $\begin{array}{l}\text { Vegetable } \\
\text { intake }\end{array}$ & $\begin{array}{l}\text { Veg \& Granola } \\
\text { intake } \\
\text { (Pre/post taste } \\
\text { food weight } \\
\text { change) }\end{array}$ & $\begin{array}{l}\text { IG group increased } \\
\text { vegetable intake at wk } \\
2 \text { compared to CG } \\
\text { ( }<0.01 \text { ) but this effect } \\
\text { was not sustained to the } \\
\text { end of intervention } \\
\text { period ( } 4 \text { weeks). } \\
\text { Granola intake } \\
\text { decreased in IG relative } \\
\text { to CG at wks } 2 \text { \& } 3 \text { but } \\
\text { NS difference at Wk4. }\end{array}$ & No LTFU & $\begin{array}{l}\text { Behavioural } \\
\text { economics }\end{array}$ \\
\hline Crespo et al. & 2012 & $\begin{array}{l}\text { Promotora } \\
\mathrm{s}\end{array}$ & $\begin{array}{l}4 \text { phone } \\
\text { calls }\end{array}$ & $\begin{array}{l}7 \\
\text { (7 months) }\end{array}$ & $\begin{array}{l}1.5 \\
\text { hours }\end{array}$ & $\begin{array}{l}\text { Healthy } \\
\text { eating \& } \\
\text { weight gain } \\
\text { prevention } \\
\text { in children }\end{array}$ & $\begin{array}{l}\text { Adiposity } \\
\text { (BMI z-score) }\end{array}$ & No & No (3 years) & SCT (HBM) \\
\hline
\end{tabular}




\begin{tabular}{|c|c|c|c|c|c|c|c|c|c|c|}
\hline \multicolumn{10}{|c|}{ Home visit intervention studies } & \multirow[b]{2}{*}{$\begin{array}{l}\text { Theoretical } \\
\text { framework }\end{array}$} \\
\hline Authors & Year & $\begin{array}{l}\text { Home } \\
\text { visitors }\end{array}$ & $\begin{array}{l}\text { Other } \\
\text { resources }\end{array}$ & $\begin{array}{l}\mathbf{N} \text { of visits } \\
\text { (intervention } \\
\text { length) }\end{array}$ & $\begin{array}{l}\text { Length } \\
\text { of } \\
\text { visits }\end{array}$ & $\begin{array}{l}\text { Target of } \\
\text { intervention }\end{array}$ & $\begin{array}{l}\text { Primary } \\
\text { outcome } \\
\text { (measure)* }\end{array}$ & $\begin{array}{l}\text { Statistically } \\
\text { significant difference } \\
\text { shown on primary } \\
\text { outcome immediate } \\
\text { IPI? }\end{array}$ & $\begin{array}{l}\text { Statistically } \\
\text { significant } \\
\text { difference shown at } \\
\text { LTFU? (LTFU } \\
\text { period) }\end{array}$ & \\
\hline Haines et al. & 2013 & $\begin{array}{l}\text { 'Health } \\
\text { educators' } \\
\text { (no further } \\
\text { description } \\
\text { provided) }\end{array}$ & $\begin{array}{l}40 \text { SMS } \\
\text { messages, } \\
\text { mailed } \\
\text { educationa } \\
1 \text { materials }\end{array}$ & $\begin{array}{l}4 \\
(6 \text { months })\end{array}$ & NR & $\begin{array}{l}\text { Family meal } \\
\text { frequency }\end{array}$ & $\begin{array}{l}\text { Family meal } \\
\text { frequency (FMF } \\
\text { question) }\end{array}$ & No & No LTFU & Not stated \\
\hline $\begin{array}{l}\text { Haire-Joshu et } \\
\text { al. }\end{array}$ & 2008 & $\begin{array}{l}\text { 'Parents as } \\
\text { teachers' } \\
\text { (existing } \\
\text { scheme) }\end{array}$ & $\begin{array}{l}\text { Computer } \\
\text { tailored } \\
\text { nutrition } \\
\text { newsletter, } \\
\text { sing along } \\
\text { storybook }\end{array}$ & $\begin{array}{l}4 \\
(\mathrm{NR})\end{array}$ & 1 hour & $\begin{array}{l}\text { Parents' \& } \\
\text { children's } \\
\text { FV intake }\end{array}$ & $\begin{array}{l}\text { Child \& parents' } \\
\text { FV intake } \\
\text { (Saint Louis } \\
\text { University for } \\
\text { Kids Food } \\
\text { Frequency } \\
\text { Questionnaire) }\end{array}$ & $\begin{array}{l}\text { Increase in F intake in } \\
\text { parents \& normal } \\
\text { weight children only (p } \\
=0.04 \& 0.05 \text { ). No } \\
\text { increase in V intake. }\end{array}$ & No LTFU & $\begin{array}{l}\text { SCT; } \\
\text { Ecological } \\
\text { framework; } \\
\text { Reciprocal } \\
\text { determinism }\end{array}$ \\
\hline $\begin{array}{l}\text { Harvey- } \\
\text { Berino \& } \\
\text { Rourke }\end{array}$ & 2003 & $\begin{array}{l}\text { Peer } \\
\text { educators }\end{array}$ & $\mathrm{n} / \mathrm{a}$ & $\begin{array}{l}11 \\
(16 \mathrm{wks})\end{array}$ & NR & $\begin{array}{l}\text { Childhood } \\
\text { obesity } \\
\text { reduction }\end{array}$ & $\begin{array}{l}\text { Adiposity } \\
\text { (Weight fo height } \\
\text { z-score) }\end{array}$ & No $(p=0.06)$ & No LTFU & Not stated \\
\hline Horton et al. & 2013 & $\begin{array}{l}\text { Promotora } \\
\mathrm{s}\end{array}$ & $\begin{array}{l}3 \text { phone } \\
\text { calls, } \\
\text { 'telenovela' } \\
\text { DVD, } \\
\text { family } \\
\text { manual }\end{array}$ & $\begin{array}{l}11 \\
\text { (4 months) }\end{array}$ & $\begin{array}{l}1.5 \\
\text { hours }\end{array}$ & $\begin{array}{l}\text { Childhood } \\
\text { obesity risk } \\
\text { behaviours }\end{array}$ & $\begin{array}{l}\text { Child FV intake } \\
\& \text { variety } \\
\text { (National Cancer } \\
\text { Institute Food } \\
\text { Attitudes \& } \\
\text { Behaviour } \\
\text { Survey) }\end{array}$ & No & No LTFU & Not stated \\
\hline Leung et al. & 2015 & $\begin{array}{l}\text { 'Parent } \\
\text { ambassado } \\
\text { rs' (local } \\
\text { volunteer } \\
\text { parents) } \\
\end{array}$ & $\begin{array}{l}\text { Illustration } \\
\text { booklet }\end{array}$ & $\begin{array}{l}20 \\
(\mathrm{NR})\end{array}$ & $\begin{array}{l}1-2 \\
\text { hours }\end{array}$ & $\begin{array}{l}\text { Feeding } \\
\text { practices }\end{array}$ & $\begin{array}{l}\text { Feeding practices } \\
\text { (Hong Kong } \\
\text { Parent Feeding } \\
\text { Questionnaire, } \\
\text { HKPFQ) }\end{array}$ & $\begin{array}{l}\text { IG scored higher on } \\
\text { HKPFQ than CG } \\
\text { indicating improved } \\
\text { practices, but practices } \\
\text { not specified }(\mathrm{p}<0.001)\end{array}$ & No LTFU & Not stated \\
\hline
\end{tabular}




\begin{tabular}{|c|c|c|c|c|c|c|c|c|c|c|}
\hline \multicolumn{10}{|c|}{ Home visit intervention studies } & \multirow[b]{2}{*}{$\begin{array}{l}\text { Theoretical } \\
\text { framework }\end{array}$} \\
\hline Authors & Year & $\begin{array}{l}\text { Home } \\
\text { visitors }\end{array}$ & $\begin{array}{l}\text { Other } \\
\text { resources }\end{array}$ & $\begin{array}{l}\mathbf{N} \text { of visits } \\
\text { (intervention } \\
\text { length) }\end{array}$ & $\begin{array}{l}\text { Length } \\
\text { of } \\
\text { visits }\end{array}$ & $\begin{array}{l}\text { Target of } \\
\text { intervention }\end{array}$ & $\begin{array}{l}\text { Primary } \\
\text { outcome } \\
\text { (measure)* }^{\text {measure }}\end{array}$ & $\begin{array}{l}\text { Statistically } \\
\text { significant difference } \\
\text { shown on primary } \\
\text { outcome immediate } \\
\text { IPI? }\end{array}$ & $\begin{array}{l}\text { Statistically } \\
\text { significant } \\
\text { difference shown at } \\
\text { LTFU? (LTFU } \\
\text { period) }\end{array}$ & \\
\hline $\begin{array}{l}\text { McGowan et } \\
\text { al. }\end{array}$ & 2013 & $\begin{array}{l}\text { Researcher } \\
\mathrm{s}\end{array}$ & $\mathrm{n} / \mathrm{a}$ & $\begin{array}{l}4 \\
(8 \mathrm{wks})\end{array}$ & NR & $\begin{array}{l}\text { Healthy } \\
\text { feeding } \\
\text { habits }\end{array}$ & $\begin{array}{l}\text { Automaticity } \\
\text { (habit strength } \\
\text { related to feeding } \\
\text { habits) } \\
\text { (Self-Report } \\
\text { Habit Index) } \\
\end{array}$ & $\begin{array}{l}\text { IG parents had higher } \\
\text { scores for giving the } \\
\text { child } 5 \mathrm{FV} \text { per day } \\
(\mathrm{p}<0.01)\end{array}$ & No LTFU & Habit theory \\
\hline $\begin{array}{l}\text { Rodearmel et } \\
\text { al. }\end{array}$ & 2006 & $\begin{array}{l}\text { Researcher } \\
\mathrm{s}\end{array}$ & $\begin{array}{l}\text { Educationa } \\
1 \operatorname{logs}\end{array}$ & $\begin{array}{l}1 \\
(13 \mathrm{wks})\end{array}$ & NR & $\begin{array}{l}\text { Weight gain } \\
\text { reduction in } \\
\text { children \& } \\
\text { parents }\end{array}$ & $\begin{array}{l}\text { Adiposity } \\
\text { (BMI for adults, } \\
\text { BMI-for-age } \\
\text { change for } \\
\text { children) }\end{array}$ & $\begin{array}{l}\text { BMI lower in IG than } \\
\text { CG in children \& } \\
\text { adults (difference }-1.12 \\
\&-0.58, p=0.03 \& \\
\mathrm{p}<0.001)\end{array}$ & No LTFU & Not stated \\
\hline Vitolo et al. & 2012 & $\begin{array}{l}\text { Undergrad } \\
\text { uate } \\
\text { students }\end{array}$ & $\begin{array}{l}\text { Leaflet } \\
\text { depicting } \\
\text { 'healthy } \\
\text { meal' } \\
\text { image }\end{array}$ & $\begin{array}{l}10 \\
\text { (12 months) }\end{array}$ & 1 hour & $\begin{array}{l}\text { Infants' } \\
\text { consumption } \\
\text { of energy } \\
\text { dense food }\end{array}$ & $\begin{array}{l}\text { Consumption of } \\
\text { sugar-dense \& } \\
\text { lipid-dense food } \\
\text { (Food frequency } \\
\text { questionnaire) }\end{array}$ & $\begin{array}{l}\text { IG infants consumed } \\
\text { fewer sugar-dense \& } \\
\text { lipid-dense foods } \\
(\mathrm{p}<0.05)\end{array}$ & $\begin{array}{l}\text { Unclear as different } \\
\text { measures reported } \\
\text { ( } \sim 3 \text { years })\end{array}$ & Not stated \\
\hline Wardle et al. & 2003 & $\begin{array}{l}\text { Researcher } \\
\mathrm{s}\end{array}$ & $\mathrm{n} / \mathrm{a}$ & $\begin{array}{l}1 \\
\text { (followed by } \\
2 \mathrm{wk} \\
\text { intervention } \\
\text { period) }\end{array}$ & NR & $\begin{array}{l}\text { Liking \& } \\
\text { intake of } \\
\text { previously } \\
\text { disliked } \\
\text { vegetable }\end{array}$ & $\begin{array}{l}\text { Vegetable liking } \\
\& \text { consumption } \\
\text { (3-point scale \& } \\
\text { weight of leftover } \\
\text { vegetable) }\end{array}$ & $\begin{array}{l}\text { Child liking, preference } \\
\text { ranking \& consumption } \\
\text { for target vegetable } \\
\text { increased in exposure } \\
\text { group \& increased by } \\
\text { more than the other } \\
\text { groups ( }<<0.001 \text { for } \\
\text { liking \& preference, } \\
\text { p }<0.01 \text { for } \\
\text { consumption) }\end{array}$ & No LTFU & Not stated \\
\hline
\end{tabular}




\begin{tabular}{|c|c|c|c|c|c|c|c|c|c|c|}
\hline \multicolumn{10}{|c|}{ Home visit intervention studies } & \multirow[b]{2}{*}{$\begin{array}{l}\text { Theoretical } \\
\text { framework }\end{array}$} \\
\hline Authors & Year & $\begin{array}{l}\text { Home } \\
\text { visitors }\end{array}$ & $\begin{array}{l}\text { Other } \\
\text { resources }\end{array}$ & $\begin{array}{l}\mathbf{N} \text { of visits } \\
\text { (intervention } \\
\text { length) }\end{array}$ & $\begin{array}{l}\text { Length } \\
\text { of } \\
\text { visits }\end{array}$ & $\begin{array}{l}\text { Target of } \\
\text { intervention }\end{array}$ & $\begin{array}{l}\text { Primary } \\
\text { outcome } \\
\text { (measure)* }\end{array}$ & $\begin{array}{l}\text { Statistically } \\
\text { significant difference } \\
\text { shown on primary } \\
\text { outcome immediate } \\
\text { IPI? }\end{array}$ & $\begin{array}{l}\text { Statistically } \\
\text { significant } \\
\text { difference shown at } \\
\text { LTFU? (LTFU } \\
\text { period) }\end{array}$ & \\
\hline Watt et al. & 2009 & $\begin{array}{l}\text { Local } \\
\text { mothers }\end{array}$ & $\mathrm{n} / \mathrm{a}$ & $\begin{array}{l}21 \\
\text { (9 months) }\end{array}$ & 1 hour & $\begin{array}{l}\text { Infant } \\
\text { feeding } \\
\text { practices at } \\
12 \mathrm{~m}\end{array}$ & $\begin{array}{l}\text { Vitamin C intake } \\
\text { (24-hr multiple } \\
\text { pass recall } \\
\text { method) }\end{array}$ & No & No (4 years) & $\begin{array}{l}\text { Social support } \\
\text { theoretical } \\
\text { model }\end{array}$ \\
\hline Wen et al. & 2012 & $\begin{array}{l}\text { Communit } \\
\text { y nurses }\end{array}$ & $\mathrm{n} / \mathrm{a}$ & $\begin{array}{l}8 \\
(2 \text { years })\end{array}$ & $\begin{array}{l}1-2 \\
\text { hours }\end{array}$ & $\begin{array}{l}\text { Infant } \\
\text { feeding } \\
\text { practices/fa } \\
\text { mily } \\
\text { nutrition }\end{array}$ & $\begin{array}{l}\text { Adiposity } \\
\text { (BMI) }\end{array}$ & $\begin{array}{l}\text { BMI lower in IG } \\
(\mathrm{p}=0.04)\end{array}$ & No (3 years) & Not stated \\
\hline Wieland et al. & 2013 & $\begin{array}{l}\text { 'Family } \\
\text { health } \\
\text { promotors' } \\
\text { from a } \\
\text { community } \\
\text { based } \\
\text { participato } \\
\text { ry research } \\
\text { partnership }\end{array}$ & $\begin{array}{l}\text { Up to } 12 \\
\text { phone calls } \\
\text { in the } 2^{\text {nd }} 6 \\
\text { months of } \\
\text { the } \\
\text { interventio } \\
n\end{array}$ & $\begin{array}{l}12 \text { ( } 6 \text { focus on } \\
\text { healthful } \\
\text { eating) } \\
\text { ( } 6 \text { months) }\end{array}$ & $\begin{array}{l}30-90 \\
\text { minutes }\end{array}$ & $\begin{array}{l}\text { Parents' \& } \\
\text { adolescents } \\
\text { dietary } \\
\text { quality }\end{array}$ & $\begin{array}{l}\text { Dietary quality } \\
\text { (Healthy Eating } \\
\text { Index, HEI/24 hr } \\
\text { recall) }\end{array}$ & $\begin{array}{l}\text { Adults in IG had higher } \\
\text { HEI score than CG at } \\
12 \mathrm{~m} \text {, but adolescents } \\
\text { did not }\end{array}$ & No LTFU & SCT \\
\hline
\end{tabular}

IPI = Immediately post-intervention

LTFU = Long Term Follow Up

$\mathrm{NR}=$ Not reported

SCT $=$ Social Cognitive Theory

HBM $=$ Health Belief Model

Promotoras $=$ Community members trained to deliver health education

*If a PO is not explicitly stated in the study, it is selected according to the aims \& objectives of the study. Where the study involves other health behaviours, the primary eating-related outcome \& behaviour has been selected. 


\section{Home visits by healthcare professionals}

The Healthy Beginnings Trial (Wen, Baur, Simpson, et al., 2012) describes a longitudinal intervention in which parents were recruited and visited by a nurse in late pregnancy and then at other time-points coinciding with developmental milestones. Key messages included breast is best, no solids until 6m, variety of FV every day, only water in cup, and active family. No explicit theoretical rationale was provided for this intervention; instead it drew on evidence-based information and guidelines. Intervention reporting for this study is of high quality, with a separate paper reporting the study design and considerable transparency around eligibility, retention and long term follow-up (LTFU). Participants represent a wider socio-economic range than most other studies reviewed. At the end of the intervention, children in the Intervention Group (IG) had a lower BMI than the Control/ Comparison Group (CG) (difference of $0.29 \mathrm{~kg} / \mathrm{m}^{2}, \mathrm{p}=0.04$ ), although both were within the healthy range defined by the authors. IG parents also reported that their children were more likely to eat one or more servings of vegetables a day, were less likely to be given food as a reward and were less likely to eat meals in front of the television. Mothers in the IG were also more likely to eat more than two servings of vegetables a day, suggesting possible mechanisms for the effects of the intervention on children (i.e. modelling \& exposure). This study was unique in attempting a cost-effectiveness analysis (Wen, Baur, Rissel, et al., 2012). It also reported one of the longest follow-up periods (3 years post-intervention); however, all significant differences between groups had disappeared by the time children were 5 years old (Wen, Baur, Simpson et al., 2015).

Healthy Habits, Happy Homes (Haines et al., 2013) involved home visits and phone calls delivered by 'health educators', accompanied by educational materials. Motivational Interviewing was employed but no further theoretical detail was provided. The intervention, 
aimed at families with 2- to 5-year-olds, focused on routine setting, predominantly through reduction of television viewing and increasing family meal frequency (FMF). Despite apparent success on some measures (reduction of TV time; lower BMI in IG), no betweengroup differences were seen in FMF. The authors noted that the high baseline FMF in both groups, and/or the imprecise wording ('at least some of the family ate together') may have contributed to a ceiling effect on this measure. Nevertheless, it seems unlikely that FMF acted as a mechanism for BMI reduction in this study.

The Healthy Immigrant Families study (Wieland et al., 2017) drew on Social Cognitive Theory (SCT) and recruited families to an intervention involving 12 home visits by family health promotors, six of which focused on healthy eating. Families comprised at least one adult and one adolescent (10 - 18 years). Adults (but not adolescents) in the IG showed an increase in Healthy Eating Index scores after 12 months compared to a CG, and after 24 months compared to baseline. Changes were not reflected in other behavioural or physiological measures collected in both groups (BMI, weight, waist circumference, blood pressure).

\section{Home visits by peer educators}

The High 5 for Kids programme (Haire-Joshu et al., 2008) involved visits focusing on knowledge, modelling of FV intake, non-coercive feeding practices and FV availability. This intervention drew on a 'combination of theoretical models', including SCT, an ecological framework and reciprocal determinism. Educators and families were participants in an existing parenting and development programme in the U.S, 'Parents as Teachers' (PAT). Thus, the IG received PAT and High 5 for Kids, while control participants received PAT only, providing a more stringent control condition than studies with limited interaction with the CG. Parents in the IG significantly increased their intake of fruit but not vegetables, 
although effects were small (parental fruit intake was, on average, 0.16 servings higher in the IG than in CG); had intention to treat analysis been employed, such small effects might not have reached significance. The change in parents' FV intake predicted the change in child FV consumption (an increase of 1 serving for parents led to an increase of 0.5 servings for children), suggesting modelling or availability as mechanisms supporting the efficacy of such interventions. However, parents did not report increased modelling; rather, they reported increased coercive feeding practices. Importantly, intervention effectiveness varied according to child weight status; FV servings increased for healthy weight but not overweight children. Families of overweight children may need more intensive or longer-lasting interventions to effectively change feeding practices and eating behaviours.

Harvey-Berino and Rourke (2003) also based their peer-educator programme on a preexisting general parent education program, Women, Infants and Children (WIC), in the US. While the existing program was delivered with the CG, the IG received an adapted program in which all sessions were related to healthy eating. Although there was some focus on the concept of parents acting as mediators to change, there was no expansion of the theoretical underpinnings of the intervention. Forty three mother-child dyads participated in this pilot study; only pre- and post-intervention data were collected. The authors noted trends towards significance in between-group differences on weight to height z-scores and energy intake (with decreases in IG and increases in CG; $\mathrm{p}=0.06$ for both). IG mothers reported significantly lower use of restrictive feeding practices than mothers in the CG group. Although this was one of the study's aims, the authors appear unclear about whether this represents a positive change. No other differences were detected on a range of outcome measures (diet, physical activity, self-efficacy, intentions, other elements of child feeding questionnaire) but the authors concluded that the pilot study showed promise and warranted 
further research. To our knowledge, a larger evaluation of the intervention has not yet been published.

The Healthy Start Visit Program (Leung, Tsang, \& Heung, 2015) aimed to improve parents' feeding practices as part of a wider program addressing health and well-being, which specifically targeted disadvantaged parents. 'Parent ambassadors' (local volunteer parents) were given 50 hours of training to deliver the intervention by psychologists and social workers. One intervention session exclusively covered healthy diet and mealtime routines (Leung, Tsang \& Heung, 2013). The theoretical framework is not stated in the paper for either the intervention as a whole or the healthy eating section. Participants in the CG attended a series of parent talks. Although no follow-up data are provided, participants in the IG had improved their feeding practices to a greater extent than those in the CG immediately post-intervention. The authors also present an interesting description of their completers and non-completers, showing that non-completers were more likely to be divorced, on lower incomes and receiving social-welfare benefits.

The 'Entre familia: reflejos de salud' study (Horton et al., 2013) employed promotoras (typically Hispanic or Latino community members trained to provide health education) to deliver a healthy eating intervention to families living on the US/Mexico border. Formative work (focus groups and depth interviews with the target population) were referenced but no psychological theory was described as background to intervention design. Weekly fast food intake decreased in the IG, and a 'trend' towards an increase in monthly FV variety was reported but there were no between-group differences on other outcome measures (FV consumption, Sugar-sweetened Beverage intake). A dose-response relationship was present, such that children who had more contact with the promotora showed greater FV intake. A process evaluation (Schmied, Parada, Horton, Ibarra, \& Ayala, 2015) indicated that number 
of visits and visit length predicted lower use of strategies to decrease fat intake, while sharing the manual with friends predicted higher use of strategies to increase fibre intake, which the authors attribute to over-reliance on the promotora and social support respectively. Greater satisfaction with the DVD (which could not be shared as it was taken away after each session) also predicted use of fibre-increase strategies. Retention rates and fidelity were high (almost $90 \%$ of families received the 11 planned visits), and the evaluation indicated high levels of satisfaction with the programme. Limitations of the study include the convenience sampling method (participants were likely to be highly motivated), self-report methodology, the possibility of contamination (IG members may have shared the manual with CG members) and the lack of follow-up data.

In the Aventuras Para Niños study (Crespo et al., 2012), mothers were allocated to a 'microintervention' (delivered by promotora in the family home), a 'macro-intervention' (delivered through school and community), 'micro + macro', or control (data collection only) conditions. This study drew on SCT (specifically, the Health Belief Model). The authors found no significant reduction in BMI z-scores for any of the groups over time. The microintervention (the condition meeting inclusion criteria for this review) had an initial effect on parenting styles; mothers in this group showed the largest increase in use of positive reinforcement. However, by the 2-year follow-up, the micro+macro group were reporting more positive reinforcement than other groups. Both these groups demonstrated a decrease in controlling strategies, indicating that home visits may be responsible for this.

Watt et al. (2009) used a 'social support theoretical model' and trained local mothers to deliver a home-visiting intervention covering exclusive breastfeeding, introducing solids, appropriate food and drink and when to cease bottle-feeding. New mothers, recruited through baby clinics, received four weekly followed by nine monthly visits, while CG 
participants received standard care from General Practitioners and Health Visitors. No between-group differences were detected in intake of Vitamin $\mathrm{C}$ or any other micro or macro nutrients at post-intervention or $6 \mathrm{~m}$ follow-up. At post-intervention, IG children were less likely to be given goats or soya milk, more likely to have 3 solid meals a day and more likely to consume apples, pears, boiled potatoes and carrots. At $6 \mathrm{~m} \mathrm{FU}$, they were less likely to be using a feeding bottle, and more likely to consume pears, potatoes and (somewhat surprisingly) chips. There were no differences between groups in terms of mothers' FV intake. Further follow up was conducted at 4 years (Scheiwe, Hardy \& Watt, 2010), when the authors found no significant differences on their primary outcome measures. IG children were more likely to be given unsweetened fruit juice and less likely to drink squash and remained less likely to use a feeding beaker or bottle, or to take a bottle to bed after their $4^{\text {th }}$ birthday. The authors concluded that the intervention had 'limited long term impact' and suggest that 'improving knowledge might not be enough to achieve behavioural changes' (p.334).

\section{Home visits by researchers (researcher-led interventions)}

Rodearmel et al. (2006) evaluated a dietary and physical activity intervention delivered through home visits by researchers. IG parent-child dyads (and other family members should they wish to take part) were asked to consume two servings of breakfast cereal per day (one for breakfast and another for a snack). No psychological rationale was provided for this, rather a biological explanation; that eating breakfast is consistently associated with successful weight management (although this depends on breakfast content, Spence, 2017), while cereal consumption can aid weight loss. The authors did not specify the cereal type, but did state that the manufacturer Kelloggs provided it. The IG was also asked to increase their daily step count by 2000 . The study targeted families with children whose percentage BMI for age $\geq$ $85^{\text {th }}$ centile. Although the IG did not achieve two portions of cereal a day, they consumed a 
mean of 1 portion, double that of the CG (who participated only in data collection). There was no pre-/post-intervention change in self-reported energy intake but IG parents and children had lower \% BMI and \% body fat (but not weight) than CG participants postintervention. The IG also significantly increased their daily step count, which is the more likely explanation for their health improvements. Furthermore, this line of research should be pursued with caution due to the high sugar content of many types of cereal.

The Healthy Feeding Habits intervention was assessed in an RCT with a no-treatment control group (McGowan et al., 2013). Parents of 2- to 6-year-olds worked through an 'intervention booklet' during researcher visits. The intervention focused on 'habit-theory' and habit forming around various feeding domains, plus self-monitoring and goal setting. At the end of the intervention, participants reported higher 'automaticity' (a measure of habit strength) and greater child fruit and vegetable intake (increases of 0.5 and 0.8 servings respectively). No follow-up data were reported. A second paper by the same group (Gardner, Sheals, Wardle, \& McGowan, 2014) concluded that the habit-forming intervention was acceptable to participants, as reflected by the high retention rate (84\%).

Vitolo, Bortolini, Campagnolo, \& Hoffman (2012) evaluated an intervention delivered to new mothers through home visits by undergraduate students. Content focused on the 'Ten Steps to Healthy Eating' (Brazilian Ministry of Health, 2002) but no further theoretical rationale was provided. Six months post-intervention (children were aged 12-16 months), there were no differences between-groups in the number of children who were overweight but IG children were less likely to consume sweets, soft drinks, honey, cookies, chocolate and salty snacks. Similarly, at 3- to 4-years old, the IG had a lower prevalence of 'poor diet' (as measured by the Healthy Eating Index, Kennedy, Ohls, Carlson \& Fleming, 1995) than the CG (Vitolo, Rauber, Campagnolo, Feldens, \& Hoffman, 2010). BMI was not reported at follow-up so no conclusions can be drawn regarding obesity prevention. 


\section{Home visits by researchers (parent-led interventions)}

Wardle et al. (2003) trialled a parent-led intervention in which parents of 2- to 6-year-olds were allocated to one of three conditions; exposure, information or control. This study did not provide a psychological theoretical framework, instead drawing from the evidence base around exposure to healthy foods as a predictor of healthy eating. The exposure group was asked to offer children a target vegetable (chosen for 'moderate' disliking by the child) every day for 14 days. The information group was given nutritional information in printed format and the CG was asked only to attend in-home data collection appointments. Using perprotocol analysis (i.e. including only those participants who followed the study protocol in analyses), the hypothesised effects were supported; liking, preference ranking and consumption of the target vegetable all increased in the exposure group. Although the CG also showed increased liking for the target vegetable, only the exposure group demonstrated a significant positive change on all three outcome measures. However, with ITT analysis, the increases in preference ranking and consumption in the exposure group were no longer significant, highlighting the challenge of persuading parents to engage in and persist with exposure strategies. This was also highlighted in post-intervention qualitative work, where several parents complained about the duration of the exposure period.

Another exposure-based intervention (Corsini, Slater, Harrison, Cooke, \& Cox, 2013) employed a market research company to support parents in delivering the intervention. Parents who stated that they found it difficult to persuade their 4- to 6-year-olds to eat vegetables were randomly assigned to exposure, exposure + reward or control groups. Both intervention groups exposed children to a target vegetable (disliked at baseline) every day for 14 days. In the exposure + reward group, parents also gave children a sticker after tasting (children could choose a 'yummy', 'okay' or 'yucky' face sticker). Liking of the vegetable 
increased equally in the two exposure groups but not in the CG. Surprisingly, consumption of the vegetable increased in all three groups. The authors attribute this finding to demand characteristics, emphasising the importance of an authentic control group. Moreover, only children who achieved 9 or more exposures (79\% of the exposure group, $60 \%$ of the exposure + reward group) were included in analyses. Fidelity of the intervention was therefore not fully tested. The authors acknowledge that intensive repeated exposure may be burdensome for many parents and that distributed exposure over longer periods might be more feasible.

Cravener et al. (2015) also used home visits by researchers to support a 4-week parent-led intervention based on behavioural economics. Participants were parents of pre-school children who consumed fewer than two vegetable portions per day and were considered at risk for obesity. After a baseline period in which vegetable consumption was measured, the IG were given vegetables in packaging with cartoon characters, stickers to use as incentives for consumption and unbranded granola bars. At snack times, children were offered the vegetables and told that, if they waited 5 minutes, they could alternatively have a granola bar. If children requested the bar but started to eat the vegetables while waiting, the granola bar option was removed on that occasion. However, as parents were allowed to offer snacks and children were allowed to request these as often as they liked, children could presumably request the granola bar immediately after consuming the vegetables. IG parents were also given some instructions around feeding practices (e.g. no pressuring, bribing, non-study rewards or pleading). CG participants were provided with the same vegetables and bars but with plain packaging and no instructions about how to offer snacks. IG children's vegetable intake increased post-intervention by approximately 1 serving per day, compared to no increase in the CG. Both groups' liking for vegetables increased over time, likely due to exposure. Because of the complex nature of this intervention, the unclear purpose of the $\mathrm{CG}$ (i.e. to control for feeding practices, branding, incentives or both of these) and confusion 
around when children were allowed to consume the granola bar, it is difficult to determine which elements of the intervention might have been effective. The sample size was also very small $(\mathrm{N}=24)$. A larger sample and more precise control groups would be required to confirm the benefits of this approach to increasing vegetable intake.

\section{Telephone-based interventions}

Three studies involved interventions primarily delivered through telephone calls. Two studies targeted FV intake in normal weight pre-school children, while one study targeted children with obesity. Table 1 summarises the characteristics of the telephone interventions, while Table 3 provides details of individual studies. 
Table 3: Telephone intervention study characteristics

\begin{tabular}{|c|c|c|c|c|c|c|c|c|c|c|}
\hline \multicolumn{10}{|c|}{ Telephone intervention studies } & \multirow[b]{2}{*}{$\begin{array}{l}\text { Theoretical } \\
\text { framework }\end{array}$} \\
\hline Authors & $\begin{array}{l}\text { Yea } \\
\mathbf{r}\end{array}$ & Callers & $\begin{array}{l}\text { Other } \\
\text { resources }\end{array}$ & $\begin{array}{l}\mathbf{N} \text { of } \\
\text { calls } \\
\text { (interv } \\
\text { ention } \\
\text { length) }\end{array}$ & $\begin{array}{l}\text { Call } \\
\text { length }\end{array}$ & $\begin{array}{l}\text { Target of } \\
\text { interventio } \\
n\end{array}$ & $\begin{array}{l}\text { Primary } \\
\text { outcome } \\
\text { (measure)* }\end{array}$ & $\begin{array}{l}\text { Statistically } \\
\text { significant } \\
\text { difference shown } \\
\text { on primary } \\
\text { outcome } \\
\text { immediate IPI? }\end{array}$ & $\begin{array}{l}\text { Statistically } \\
\text { significant } \\
\text { difference } \\
\text { shown at } \\
\text { LTFU? }\end{array}$ & \\
\hline $\begin{array}{l}\text { Makert } \\
\text { et al. }\end{array}$ & 2014 & $\begin{array}{l}\text { Trained } \\
\text { prevention } \\
\text { managers }\end{array}$ & Newsletter & $\begin{array}{l}14 \\
(12 \\
\text { months })\end{array}$ & $\begin{array}{l}20-30 \\
\text { minut } \\
\text { es }\end{array}$ & $\begin{array}{l}\text { Child } \\
\text { obesity } \\
\text { prevention }\end{array}$ & $\begin{array}{l}\text { Child adiposity } \\
\text { (BMI-SDS) }\end{array}$ & $\begin{array}{l}\text { More of the IG } \\
\text { reduced BMI-SDS } \\
\text { by } \geq 0.2 \text { than } \mathrm{CG} \\
(\mathrm{P}=0.03 \text { with } \mathrm{PPA} \\
\text { only) }\end{array}$ & No LTFU & Not stated \\
\hline $\begin{array}{l}\text { Tabak et } \\
\text { al. }\end{array}$ & 2012 & Dieticians & Newsletter & $\begin{array}{l} \\
(4 \\
\text { months })\end{array}$ & $\begin{array}{l}34 \\
\text { minut } \\
\text { es }\end{array}$ & $\begin{array}{l}\text { Pre-school } \\
\text { children's } \\
\text { vegetable } \\
\text { intake }\end{array}$ & $\begin{array}{l}\text { Child } \\
\text { vegetable } \\
\text { intake } \\
\text { (Block Kids } \\
\text { Food } \\
\text { Frequency } \\
\text { Questionnaire) }\end{array}$ & No & No LTFU & SCT \\
\hline $\begin{array}{l}\text { Wyse et } \\
\text { al. }\end{array}$ & 2012 & $\begin{array}{l}\text { 'Experience } \\
\mathrm{d} \text { health } \\
\text { interviewers } \\
\text { ' (no further } \\
\text { information } \\
\text { ) }\end{array}$ & $\begin{array}{l}\text { Guidebook } \\
\text {, meal } \\
\text { planner, } \\
\text { cookbooks } \\
\text {, water } \\
\text { bottle }\end{array}$ & $\begin{array}{l}4 \\
(4 w k)\end{array}$ & $\begin{array}{l}30 \\
\text { minut } \\
\text { es }\end{array}$ & $\begin{array}{l}\text { Home food } \\
\text { environmen } \\
\text { t associated } \\
\text { with } \\
\text { children's } \\
\text { FV } \\
\text { consumptio } \\
\text { n }\end{array}$ & $\begin{array}{l}\text { FV intake } \\
\text { (Children's } \\
\text { Dietary } \\
\text { Questionnaire) }\end{array}$ & $\begin{array}{l}\text { FV scores higher } \\
\text { in IG than CG at } \\
2 \mathrm{~m} \text { with ITT } \\
(\mathrm{p}=0.008)\end{array}$ & $\begin{array}{l}\text { FV scores } \\
\text { higher in IG } \\
\text { than CG at } \\
6 \mathrm{~m} \text { with PPA } \\
(\mathrm{p}=0.021) \\
\text { and at } 12 \mathrm{~m} \\
\text { with ITT } \\
(\mathrm{p}<0.001)\end{array}$ & $\begin{array}{l}\text { Conceptual } \\
\text { model of } \\
\text { family-based } \\
\text { intervention } \\
\text { behaviour } \\
\text { change } \\
\text { techniques }\end{array}$ \\
\hline
\end{tabular}

IPI = Immediately post-intervention

*If a PO is not explicitly stated in the study, it is selected according to the aims \& objectives of the study. Where the study involves other health behaviours, the primary eating-related outcome \& behaviour have been selected.

PPA $=$ Per protocol analysis 
The widely-reported Healthy Habits intervention used an RCT design to test the efficacy of a telephone-based intervention to increase preschoolers' FV intake (Wolfenden et al., 2014; Wyse, Campbell, Brennan, \& Wolfenden, 2014; Wyse, Wolfenden, \& Bisquera, 2015; Wyse et al., 2012; Wyse et al., 2010). Telephone calls were delivered by trained and supervised telephonists using computer-assisted telephone calls (CATI). The intervention drew on Golan \& Weizman's conceptual model of family-based interventions (Golan \& Weizman, 2001) and used a number of behaviour change techniques (e.g. goal-setting). Interviewers were discouraged from deviating from the script to ensure standardisation. The CG received one booklet on dietary guidelines through the post. The study was followed up at 6,12 and 18 months (5, 11 and 17 months after completion of intervention, respectively). Both parent and child FV intake increased as a result of the intervention. FV increase was significantly higher for children in the IG than those in the CG one month post-intervention. At 6 months, this difference remained significant in analyses using all available data and per-protocol analyses, and approached significance with sensitivity analysis using baseline observation carried forward $(\mathrm{BOCF})(\mathrm{p}=0.069)$. Effect sizes are not reported, but the main analysis shows that the IG increased by 2 points at both 1 month and 6 month assessments; each point denoted an additional portion of FV or a newly-tried FV in the past 24 hours, suggesting a meaningful change. However, mean scores for both groups at baseline were $>14$, indicating that children were already meeting Australian Dietary Guidelines. Furthermore, parents in the sample were more educated and had a higher household income than a random sample of parents from the region, indicating that the intervention did not reach the families most in need. Nevertheless, subgroup analysis indicated that the intervention was effective for children in the sample who were not reaching the recommended daily allowance at baseline, and that these effects lasted for at least $12 \mathrm{~m}$ (although the between-group difference was no longer significant at $18 \mathrm{~m}$ ), 
suggesting that there would be merit in re-testing the intervention with a disadvantaged sample.

Tabak, Tate, Stevens, Siega-Riz and Ward (2012) evaluated an intervention comprising two motivational telephone calls and four newsletters. Parents of 2- to 5-year-olds were asked to select one of four target areas: picky eating, vegetable availability, modelling and family meal frequency. The authors stated that these areas were specifically chosen because of their relevance to Social Cognitive Theory. No participant chose modelling or family meal frequency, suggesting that they did not see a need for improvement in these areas or consider such improvements to be important. Increased vegetable availability was detected postintervention in the IG (although group was not a significant predictor of availability, there was a significant group difference in change in availability), along with increased offering of FV as a snack and decreased cooking of separate meals due to the child demanding something different. There were no significant differences between the IG and CG groups' vegetable intake immediately post-intervention; it is feasible that more time may have been needed for changes in parental behaviour to translate into changes in child intake. No evidence of any dose-dependent effects was seen, although the study had a very small sample and was underpowered. The authors acknowledge that their sample was also relatively high in socio-economic status and that parents' reporting of children's diets might have been inaccurate due to the time children spent in childcare. However, the finding of effects within such a small sample indicates that the intervention warrants further investigation.

The Telephone-Based Adiposity Prevention for Families with Overweight Children (TAFF) study (Markert et al., 2014) also used CATI and supporting printed material (a newsletter delivered by post or email). This obesity prevention intervention focused on medical aspects of obesity, dietary habits, eating behaviour, physical activity, leisure activity, psychological 
support and stress. Its design drew on therapy approaches (specifically family therapy and solution-focused systemic therapy) but the authors did not expand on the theoretical rationale beyond this. Parent-child triads were recruited where young people were aged between 4 and 17 years old and had a BMI-SDS $\geq 90^{\text {th }}$ centile. Strengths of this study included its duration and the pragmatic nature of recruitment (through Cresnet, a German association of independent paediatricians, with whom participants were registered). Unfortunately, a significant intervention effect identified with per-protocol analysis disappeared with ITT analysis. The authors also note that most young people $\geq 10$ years old (who were interviewed separately from their parents) claimed to have 'very good eating habits' at baseline, which, given the children's adiposity, raises questions around the validity of self-report dietary measures in young people. Also of concern, of 3387 eligible families contacted by paediatricians, only $13 \%$ expressed an interest in the study, and $9 \%$ consented to take part. Coupled with the high attrition rate within the IG (63\%, compared to $22 \%$ in the CG), the intervention clearly failed to appeal to families. Predictors of non-participation included believing that the family already practiced a healthy lifestyle, being unwilling to make lifestyle changes, greater subjective physical wellbeing and eating irregular breakfasts (Alff et al., 2012). The authors concluded that 'even a low-threshold intervention program does not reach the families who really need it' (p.1). A further limitation is that data was collected immediately post-intervention with, to our knowledge, no subsequent follow up. Given the small effect of the intervention and the fact that most other studies see a decrease in effects over time, it is unlikely that this telephone intervention would achieve long-term benefits. 


\section{INFORMATION/TECHNOLOGY-DELIVERED INTERVENTIONS}

\section{Printed materials}

Nine studies involved interventions delivered through printed materials alone. Studies were included in this section of the review if printed information was the active intervention under evaluation; studies using printed information as the control condition are reported elsewhere. Three studies included more than one intervention; in each case, only the printed materials condition qualified for inclusion in the review. Table 1 provides a summary of the studies delivered through printed materials, while Table 4 provides details of individual studies. 
Table 4: Printed materials intervention study characteristics

\begin{tabular}{|c|c|c|c|c|c|c|c|c|}
\hline \multicolumn{8}{|c|}{ Printed information intervention studies } & \multirow[b]{2}{*}{$\begin{array}{l}\text { Theoretical } \\
\text { framework }\end{array}$} \\
\hline Authors & Year & $\begin{array}{l}\text { Type of } \\
\text { information }\end{array}$ & $\begin{array}{l}\text { Correspondence } \\
\mathbf{N} \\
\text { (intervention } \\
\text { length when } \\
\mathbf{N}>1 \text { ) }\end{array}$ & $\begin{array}{l}\text { Target of } \\
\text { intervention }\end{array}$ & $\begin{array}{l}\text { Primary outcome } \\
\text { (measure)* }\end{array}$ & $\begin{array}{l}\text { Statistically } \\
\text { significant difference } \\
\text { shown on primary } \\
\text { outcome immediate } \\
\text { IPI? }\end{array}$ & $\begin{array}{l}\text { Statistically } \\
\text { significant } \\
\text { difference } \\
\text { shown at } \\
\text { LTFU? } \\
\text { (LTFU period) } \\
\end{array}$ & \\
\hline Croker et al. & 2012 & $\begin{array}{l}\text { Personalised } \\
\text { 'family } \\
\text { information } \\
\text { pack' }\end{array}$ & 1 & $\begin{array}{l}\text { Children's } \\
\text { unhealthy eating }\end{array}$ & $\begin{array}{l}\text { None identified as } \\
\text { primary. } \\
\text { (SR BMI, 4-food } \\
\text { frequency } \\
\text { questionnaire to } \\
\text { calculate over all } \\
\text { healthy eating score) }\end{array}$ & $\begin{array}{l}\text { No (data collected } 6 \mathrm{~m} \\
\text { PI) }\end{array}$ & $\begin{array}{l}\text { No additional } \\
\text { LTFU }\end{array}$ & Not stated \\
\hline $\begin{array}{l}\text { Estabrooks et } \\
\text { al. }\end{array}$ & 2009 & $\begin{array}{l}\text { Workbook with } \\
\text { 'targeted } \\
\text { intervention } \\
\text { days' }\end{array}$ & 1 & $\begin{array}{l}\text { Healthy lifestyle } \\
\text { behaviours }\end{array}$ & $\begin{array}{l}\text { Child adiposity } \\
\text { (BMI z-score) }\end{array}$ & $\begin{array}{l}\text { No change at } 6 \mathrm{~m} \text { post- } \\
\text { baseline (unclear how } \\
\text { long intervention lasts) }\end{array}$ & $\begin{array}{l}\text { Within subjects } \\
\text { BMI reduction } \\
\text { in workbook } \\
\text { condition } \\
(\mathrm{p}<0.05) \text { but no } \\
\text { between groups } \\
\text { change }(12 \mathrm{~m}) \\
\end{array}$ & $\begin{array}{l}\text { Socio- } \\
\text { ecologic } \\
\text { theory }\end{array}$ \\
\hline $\begin{array}{l}\text { Gholami et } \\
\text { al. }\end{array}$ & 2014 & Leaflet & 1 & $\begin{array}{l}\text { Mothers' self- } \\
\text { regulatory skills } \\
\text { for providing } \\
\text { vegetables to } \\
\text { children } \\
\end{array}$ & $\begin{array}{l}\text { Child vegetable intake } \\
\text { (Study-specific } \\
\text { question) }\end{array}$ & $\begin{array}{l}\text { Vegetable intake } \\
\text { higher in IG than CG } \\
\text { 2-weeks }(p=0.04)\end{array}$ & No $(3 \mathrm{~m})$ & $\begin{array}{l}\text { Behaviour } \\
\text { change } \\
\text { theory }\end{array}$ \\
\hline Hart et al. & 2016 & $\begin{array}{l}2 \text { booklets, } \\
\text { poster, children's } \\
\text { book, } \\
\text { accompanying } \\
\text { website }\end{array}$ & 1 & $\begin{array}{l}\text { Healthy eating, } \\
\text { weight } \\
\text { management and } \\
\text { body satisfaction } \\
\text { in childhood }\end{array}$ & $\begin{array}{l}\text { Child adiposity, } \\
\text { parental knowledge, } \\
\text { family meal } \\
\text { characteristics, } \\
\text { parental feeding } \\
\text { practices } \\
\text { (various Likert scale } \\
\text { measures, child BMI-z } \\
\text { scores) }\end{array}$ & $\begin{array}{l}\text { Yes, but not for } \\
\text { workbook condition }\end{array}$ & No (6 wks) & Not stated \\
\hline
\end{tabular}




\begin{tabular}{|c|c|c|c|c|c|c|c|c|}
\hline \multicolumn{8}{|c|}{ Printed information intervention studies } & \multirow[b]{2}{*}{$\begin{array}{l}\text { Theoretical } \\
\text { framework }\end{array}$} \\
\hline Authors & Year & $\begin{array}{l}\text { Type of } \\
\text { information }\end{array}$ & $\begin{array}{l}\text { Correspondence } \\
\mathbf{N} \\
\text { (intervention } \\
\text { length when } \\
\mathrm{N}>1 \text { ) }\end{array}$ & $\begin{array}{l}\text { Target of } \\
\text { intervention }\end{array}$ & $\begin{array}{l}\text { Primary outcome } \\
\text { (measure)* }\end{array}$ & $\begin{array}{l}\text { Statistically } \\
\text { significant difference } \\
\text { shown on primary } \\
\text { outcome immediate } \\
\text { IPI? }\end{array}$ & $\begin{array}{l}\text { Statistically } \\
\text { significant } \\
\text { difference } \\
\text { shown at } \\
\text { LTFU? } \\
\text { (LTFU period) }\end{array}$ & \\
\hline Heath et al. & 2014 & Picture books & 1 & $\begin{array}{l}\text { Child's willingness } \\
\text { to look at, taste and } \\
\text { consume } \\
\text { vegetables }\end{array}$ & $\begin{array}{l}\text { Child's visual } \\
\text { preference for target } \\
\text { vegetable } \\
\text { Child's willingness to } \\
\text { taste target vegetable } \\
\text { Child's intake of target } \\
\text { vegetable } \\
\text { (child offered choice of } \\
\text { FV in all cases) }\end{array}$ & $\begin{array}{l}\text { Toddlers looked at } \\
\text { target vegetable for } \\
\text { longer than control } \\
\text { ( }<<0.001 \text { ) } \\
\text { No significant } \\
\text { difference between } \\
\text { willingness to taste } \\
\text { target vs control } \\
\text { vegetable } \\
\text { Toddlers consumed } \\
\text { more of target than } \\
\text { control vegetable } \\
\text { ( } \mathrm{p}=0.016 \text { ) }\end{array}$ & No LTFU & Not stated \\
\hline $\begin{array}{l}\text { Houston- } \\
\text { Price et al. }\end{array}$ & 2009 & Picture books & 1 & $\begin{array}{l}\text { Child's willingness } \\
\text { to taste }\end{array}$ & $\begin{array}{l}\text { Child's willingness to } \\
\text { taste } \\
\text { (child offered choice of } \\
\text { FV) }\end{array}$ & No & No LTFU & Not stated \\
\hline Looney et al. & 2014 & $\begin{array}{l}\text { Monthly } \\
\text { newsletter }\end{array}$ & $\begin{array}{l}6 \\
(6 \text { months })\end{array}$ & $\begin{array}{l}\text { Childhood } \\
\text { obesity/overweight }\end{array}$ & $\begin{array}{l}\text { Child adiposity } \\
\text { (BMI z-score) }\end{array}$ & $\begin{array}{l}\text { BMI } z \text {-score reduced } \\
\text { for whole sample } \\
(p<0.036)\end{array}$ & No LTFU & Not stated \\
\hline Pearson et al. & 2010 & $\begin{array}{l}\text { Separate } \\
\text { newsletters for } \\
\text { parents and } \\
\text { children }\end{array}$ & $\begin{array}{l}2 \text { each } \\
(1 \text { month })\end{array}$ & $\begin{array}{l}\text { FV consumption in } \\
\text { adolescents }\end{array}$ & $\begin{array}{l}\text { FV consumption } \\
\text { (previously validated } \\
\text { youth FFQ) }\end{array}$ & $\begin{array}{l}\text { IG adolescents } \\
\text { reported higher fruit } \\
(\mathrm{p}<0.01) \text { and vegetable } \\
(\mathrm{p}<0.05) \text { consumption } \\
\text { than } \mathrm{CG}\end{array}$ & $\begin{array}{l}\text { IG adolescents } \\
\text { reported higher } \\
\text { fruit }(\mathrm{p}<0.01) \\
\text { and vegetable } \\
(\mathrm{p}<0.05) \\
\text { consumption } \\
\text { than } C G(6 \mathrm{wks})\end{array}$ & $\begin{array}{l}\text { Behavioral } \\
\text { choice } \\
\text { theory; } \\
\text { SCT }\end{array}$ \\
\hline
\end{tabular}




\begin{tabular}{|c|c|c|c|c|c|c|c|c|}
\hline \multicolumn{8}{|c|}{ Printed information intervention studies } & \multirow[b]{2}{*}{$\begin{array}{l}\text { Theoretical } \\
\text { framework }\end{array}$} \\
\hline Authors & Year & $\begin{array}{l}\text { Type of } \\
\text { information }\end{array}$ & $\begin{array}{l}\text { Correspondence } \\
\mathbf{N} \\
\text { (intervention } \\
\text { length when } \\
\mathbf{N}>1 \text { ) }\end{array}$ & $\begin{array}{l}\text { Target of } \\
\text { intervention }\end{array}$ & $\begin{array}{l}\text { Primary outcome } \\
\text { (measure)* }\end{array}$ & $\begin{array}{l}\text { Statistically } \\
\text { significant difference } \\
\text { shown on primary } \\
\text { outcome immediate } \\
\text { IPI? }\end{array}$ & $\begin{array}{l}\text { Statistically } \\
\text { significant } \\
\text { difference } \\
\text { shown at } \\
\text { LTFU? } \\
\text { (LTFU period) }\end{array}$ & \\
\hline $\begin{array}{l}\text { Wrieden \& } \\
\text { Levy }\end{array}$ & 2016 & $\begin{array}{l}\text { 'Smart swaps' } \\
\text { information } \\
\text { pack }\end{array}$ & 1 & $\begin{array}{l}\text { Purchasing } \\
\text { behaviour of } \\
\text { children's snacks }\end{array}$ & Self-reported swaps & $\begin{array}{l}\text { IG reported more } \\
\text { swaps to lower-fat } \\
\text { dairy products, lower- } \\
\text { sugar drinks and } \\
\text { lower-sugar cereal } \\
(\mathrm{p}<0.001, \mathrm{p}=0.01, \\
\mathrm{p}=0.009)\end{array}$ & No LTFU & Not stated \\
\hline
\end{tabular}

IPI = Immediately post-intervention

*If a PO is not explicitly stated in the study, it is selected according to the aims \& objectives of the study. Where the study involves other health behaviours, the primary eating outcome \& behaviour have been selected.

$\mathrm{FFQ}=$ Food frequency questionnaire

SCT $=$ Social Cognitive Theory 
Change for Life is a UK-based national obesity prevention program. One element of the campaign is an information pack for families, which was evaluated with parents of 5- to 11year-olds (Croker, Lucas, \& Wardle, 2012). After completing a baseline questionnaire, parents in the IG were sent standard Change for Life materials and a 'How are the Kids?' questionnaire, on completion of which they received a personalised family information pack. The CG received 'standard exposure to healthy lifestyle messages'. Due to extremely low response rates to the second questionnaire (of the 3774 families who signed up, 98 returned the questionnaire, only three of whom were in the CG), the protocol was adjusted; parents who did not complete the questionnaire were sent an un-personalised family information pack. At a 6-month follow-up, responses were obtained from $29 \%$ and $46 \%$ of the original samples in the IG and CG, respectively. No significant changes from pre- to post-intervention were found on any measure (monitoring, modelling, child FV intake, child sugar intake, PA duration, snacking and regular mealtimes) and parents in the IG placed less importance on physical activity than those in the CG. The authors provide a transparent and detailed list of potential explanations for the lack of success, including lack of theoretical basis, lack of clarity over the target audience (children or parents), targeting too many complex behaviours and CG contamination. For example, the authors acknowledge that the lack of focus to the intervention was demonstrated by the failure to refer to 'obesity' in the materials used, despite obesity prevention being the primary aim. Feedback from focus groups also suggested that some parents found the materials 'patronising' or 'unrealistic'.

Wrieden and Levy (2016) evaluated the Smart Swaps element of the Change4Life campaign, which focuses on reducing the fat and sugar content of children's snacks through information packs suggesting healthy swaps. As with the Change4Life study described above, the Smart 
Swaps study did not report any theoretical rationale. Self-reported purchasing behaviour indicated that parents in the IG implemented more 'smart swaps' than those in the CG one and two weeks after receiving the packs, but no longer-term follow-up data were collected. Further limitations were that IG and CG participants lived in different geographical regions, that participants were not randomly allocated to groups, and that many of the CG had heard of the campaign (13\% had signed up to it). The low retention rate in the IG (55\%) further limits the conclusions that can be drawn about behaviour change within the whole sample.

Estabrooks et al. (2009) ran a study with three conditions, one of which was delivered in the home, satisfying criteria for inclusion in this review. Parent-child dyads were recruited when children were aged 8 to 12 years and $\geq 85^{\text {th }}$ percentile in BMI. Parents were provided with Family Connections workbooks, including 'intervention homework assignments'. The intervention was based on Golan and Weizman's model which purports that parents are the agent of children's eating behaviour change (Golan \& Weizman, 2001). Results were inconsistent: children showed a within-group decrease in BMI z-scores at 12-month follow up (but not at 6 months) but there were no between-group differences. The study was also underpowered due to the high attrition rates, raising the possibility of a Type I error.

Pearson, Atkin, Biddle, \& Gorely (2010) carried out a newsletter-based intervention targeting adolescent children (12-14 years), drawing on 'Behavioural Choice Theory' and Social Cognitive Theory. The adolescents' newsletters targeted normative beliefs, health and nutritional knowledge, aiming to increase FV preferences and 'improve behavioural skills and healthy eating' (p.877). The parents' newsletters targeted nutritional knowledge, parents' FV intake and FV accessibility and availability. Post-intervention, parents and adolescents in the IG reported increased consumption of fruits and vegetables; parents also reported increased availability and accessibility. Results appeared to be robust and consistent with 
medium-large effect sizes $\left(\eta^{2}=0.08-0.32\right.$ for the above findings $)$, most likely due to the intervention's basis in theory, and the provision of targeted messaging for parents and children. However, the sample was mostly of relatively high social-economic status, and desirability may have played a role in responses in this study. Follow-up data collected 6weeks post intervention were consistent with initial findings; whether effects are maintained in the longer-term remains unknown. Nevertheless, the promising results warrant a larger randomised controlled trial, which could also explore whether higher doses are able to maintain effects.

The Confident Body, Confident Child (CBCC) programme (Hart, Damiano, \& Paxton, 2016) aims to change parenting behaviours and strategies around food. Resources consist of booklets (one on parenting strategies, another for extended family members), a "Do's and Don'ts" poster, an evidence-based children's book with messages about appearance and selfworth, and an associated $C B C C$ website. The evaluation involved two intervention groups, both of whom received the $C B C C$ materials; one group additionally participated in a parenting workshop. There were two control groups: nutritional information and wait-list. The IG who took part in the workshop demonstrated the greatest behaviour change, suggesting limitations to the benefits of simply receiving information booklets. However, some outcome measures demonstrated improvement in both IGs, with no between-group differences (e.g. knowledge, parenting intention, weight restriction), while others showed equivalent benefits in all groups other than the wait-list CG (e.g. instrumental feeding, emotional feeding, pushing to eat). Thus, the nature and intensity of the intervention appears to matter more for some behavioural outcomes than for others. The study acknowledges the difficulties around self-report measures and the high socio-economic status of participants. To enable parents who lived further away from the study centre to participate, all potential participants were asked whether they could attend the workshop, and responses were taken 
into account when allocating participants to groups (i.e. those who could not attend were not allocated to the workshop condition). Steps were taken to ensure even distribution and attrition rates were not noticeably larger in any group (statistical differences not reported). However, by attempting to be inclusive, the authors may have inadvertently assigned more engaged participants, willing to travel to the workshops, to the IG that participated in these. Nevertheless, the $C B C C$ intervention was evidence-based and transparently reported; future work could address the necessity of the workshop component to the intervention.

Looney and Raynor (2014) compared outcomes between a group who received printed materials alone versus groups who received newsletters alongside higher intensity interventions (regular growth monitoring with or without counselling). No theoretical rationale was explicitly mentioned. Children all had a BMI $z$ score $\geq 85^{\text {th }}$ centile at baseline. All groups showed a decrease in BMI z-score, but effect sizes grew as intervention intensity increased. Sugar-sweetened beverage consumption also decreased over time but no group effects or effect sizes were reported. No changes were seen on other outcome variables (FV intake, moderate-to-vigorous physical activity total energy intake, percentage energy from fat). Because there was no 'inactive' control group, it is impossible to ascertain whether the changes seen were due to participation in the study; this highlights the need for a proper control condition when comparing interventions.

Gholami, Wiedemann, Knoll, \& Schwarzer (2015) investigated the efficacy of a 'theorybased' leaflet, targeted at mothers and aiming to increase their daughters' (aged $6-11$ years) vegetable intake. Little information or theoretical explanation is given about leaflet contents other than that they drew on Michie et al.'s (2011) behaviour change techniques. Although increased vegetable intake was reported in the IG compared to the CG two weeks postintervention, the difference had disappeared by three months. 
Houston-Price, Butler and Shiba (2009) introduced printed information into the family home through the novel use of picture books, with the aim of supporting healthy eating through exposure to pictures of foods. This study aimed to build on the evidence base indicating that exposure to new foods can increase children's willingness to try them but did not cite any specific underpinning theory behind intervention design. Families with toddlers received one of two books through the post containing familiar and unfamiliar fruits and vegetables. 'Willingness to taste' tests were conducted after 14 consecutive days of reading the books. The study was controlled through a within-subjects design; each food served as an exposed or non-exposed food for different children, controlling for any preferences for specific foods. A main effect of familiarity was seen, along with an interaction between familiarity and exposure; children were more likely to try unfamiliar foods that they had been exposed to but less likely to try familiar foods they had been exposed to.

Heath, Houston-Price and Kennedy (2014) built on these findings with a further experiment addressing the effects of picture-book exposure on willingness to taste vegetables, due to the 'particular challenge' that vegetables present for healthy eating interventions. Toddlers were randomised to receive a picture book in the post about a liked, disliked, or unfamiliar vegetable, which parents were asked to read with the child for 5 minutes every day for two weeks. No significant differences in willingness to taste target versus control vegetables were seen in any IG. However, children consumed more of the target vegetable than the corresponding control vegetable when foods were initially unfamiliar. The authors suggest that this may be due to the 'learned safety' of exposed foods, or to the lack of 'pre-existing schemas' for unfamiliar foods. They also discuss the importance of parents' role in reading the book with the child, emphasising the need for a 'positive attitude' and citing an example of a parent who said 'Yuk!' at the end of every page, whose child did not show any positive exposure effects. 


\section{Game-based interventions}

Video games have also been investigated as vehicles for delivering healthy eating and weight management interventions to adolescents. Two studies used non-active video-games (NonAVG) as engaging ways to promote dietary change. Two further studies involved active video-games (AVG), which encourage physical activity by requiring active participation for success; these are included in this review as they cite decreased snacking as a secondary aim.

Table 1 summarises these studies' characteristics, while Table 5 provides details of individual studies. 
Table 5: Video gaming intervention study characteristics

\begin{tabular}{|c|c|c|c|c|c|c|c|c|}
\hline \multicolumn{8}{|c|}{ Video game interventions } & \multirow[b]{2}{*}{$\begin{array}{l}\text { Theoretical } \\
\text { framework }\end{array}$} \\
\hline Authors & Year & $\begin{array}{l}\text { AVG/ } \\
\text { Non- } \\
\text { AVG }\end{array}$ & $\begin{array}{l}\text { Session } \\
\mathbf{N}\end{array}$ & $\begin{array}{l}\text { Target of } \\
\text { intervention }\end{array}$ & $\begin{array}{l}\text { Primary } \\
\text { outcome } \\
\text { (measure)* }\end{array}$ & $\begin{array}{l}\text { Statistically significant } \\
\text { difference shown on } \\
\text { primary outcome } \\
\text { immediate IPI? }\end{array}$ & $\begin{array}{l}\text { Statistically } \\
\text { significant difference } \\
\text { shown at LTFU? } \\
\text { (LTFU period) }\end{array}$ & \\
\hline Baranowski et al. & 2011 & $\begin{array}{l}\text { Non- } \\
\text { AVG }\end{array}$ & 9 & Diet and PA & $\begin{array}{l}\text { Child FV } \\
\text { intake } \\
(24 \mathrm{hr} \text { recall }) \\
\end{array}$ & $\begin{array}{l}\text { IPI and FU not reported } \\
\text { separately. }\end{array}$ & $\begin{array}{l}\text { FV intake increased in } \\
\text { IG relative to } C G \\
(p=0.018)(2 \mathrm{~m})\end{array}$ & $\begin{array}{l}\text { SCT; } \\
\text { SDT; } \\
\text { Persuasion theory }\end{array}$ \\
\hline Maddison et al. & 2013 & AVG & NR & Snacking & BMI & $\begin{array}{l}\text { BMI decreased in IG } \\
\text { group }(\mathrm{p}=0.02) \text { but no } \\
\text { significant difference for } \\
\text { self-reported snacking }\end{array}$ & No LTFU & $\begin{array}{l}\text { Behavioural economic } \\
\text { theory }\end{array}$ \\
\hline Simons et al. & 2015 & AVG & NR & Snacking & BMI-SDS & $\begin{array}{l}\text { CG decreased BMI-SDS } \\
\text { by more than IG (p value } \\
\text { not reported) }\end{array}$ & No $(10 \mathrm{~m})$ & $\begin{array}{l}\text { SDT: } \\
\text { TPB }\end{array}$ \\
\hline Thompson et al. & 2015 & $\begin{array}{l}\text { Non- } \\
\text { AVG }\end{array}$ & 10 & $\begin{array}{l}\text { Child FV } \\
\text { intake }\end{array}$ & $\begin{array}{l}\text { Child FV } \\
\text { intake } \\
(24 \mathrm{hr} \text { recall) }\end{array}$ & $\begin{array}{l}\text { FV intake increased in } \\
\text { 'Action' IG only } \\
(p<0.0001)\end{array}$ & $\begin{array}{l}\text { FV intake increased in } \\
\text { 'Action' IG only } \\
(\mathrm{p}<0.0001)(3 \mathrm{~m})\end{array}$ & $\begin{array}{l}\text { SCT: } \\
\text { SDT; } \\
\text { Elaboration likelihood } \\
\text { model } \\
\text { Behavioural } \\
\text { inoculation } \\
\text { Maintenance theories }\end{array}$ \\
\hline
\end{tabular}

IPI = Immediately post-intervention

*If a PO is not explicitly stated in the study, it is selected according to the aims \& objectives of the study. Where the study involves other

health behaviours, the primary eating outcome \& behaviour have been selected.

$\mathrm{NR}=$ not reported

AVG = Active Video Game

SCT $=$ Social Cognitive Theory

SDT $=$ Self Determination Theory

$\mathrm{TPB}=$ Theory of Planned Behaviour 
Non-active video games. Baranowski et al. (2011) investigated the efficacy of a video game as an agent for changing eating behaviour in adolescents aged 10 to 12 years. A CG received 'knowledge-enhancing' materials about healthy eating, including nutrition-based computer games. This was designed to act as a control but to 'meet recruitees' expectations of playing health-related video games' (p.3). The intervention was described as drawing on Social Cognitive Theory (SCT), Self-Determination Theory (SDT) (Deci, 2012) and persuasion models. An increase in FV intake was seen in the IG two months after post-intervention; the effect size was small (Cohen's $d=0.18$ ), equating to an increase of 0.67 portions to a total of 2.15 portions per day, considerably lower than recommended guidelines. However, dietary data collection took place through $24 \mathrm{hr}$ dietary recall, the validity of which is often questioned (Ioannidis, 2013). There were no between-group differences on other outcome measures (water intake, physical activity or body composition) and no long-term follow-up data were provided. By the authors' own admission, the study was underpowered and would benefit from replication with a larger sample. It is also worth noting that sedentary behaviour increased in the intervention group (albeit not significantly), raising the possibility that any positive health behaviour changes brought about by non-active video games might be negated by increased screentime.

The same research group also evaluated a video game that encouraged the setting of implementation intentions by 9- to 11-year-old children (Thompson et al., 2015). This also drew on SCT and SDT, as well as an elaboration likelihood model (Petty \& Brinol, 2012), 'behavioural inoculation' and maintenance theories. Building on a previous school-based trial of the 'Squire’s Quest!' video game (Baranowski et al., 2003), 'Squires Quest II' was developed for home delivery, with a parallel parental component; parents received a relevant 
newsletter alongside each of the 10 game episodes. Participants were randomly allocated to one of four groups: Action (goal setting and action intentions, i.e. planning how to achieve goals), Coping (goal setting and coping intentions, i.e. identifying barriers to goals and describing coping strategies), Both Action and Coping, or None. Compared to baseline, the Coping and Action groups showed increased FV intake following the 3-month-long intervention. At the final follow-up, 3 months later, only the Action group maintained the increase; this equated to 0.68 servings per day, almost a $50 \%$ increase from baseline. Nevertheless, FV intake for all groups remained well below recommended daily guidelines. The authors noted their surprise in finding that participants in the 'Both' group showed no change in FV intake, and suggested that the cognitive load involved in setting two different types of implementation intention might be too demanding at this age. Again, the study relied on children's self-reported FV intake, which was not compared to parents' reports. Interestingly, a process evaluation showed that, although child participation was consistently high (91\% completed all 10 episodes, with no between-group differences), parental involvement varied widely; around a third reported that they had read three or fewer of the 10 newsletters. This is an important finding, given the widely-held assumption that parents are the agent of change in relation to children's eating (Golan, 2006). While an intervention aimed at the child may invoke behaviour change in children's asking behaviour, preferences or willingness to consume FV, parents must facilitate availability and accessibility for these effects to lead to dietary changes. Conclusions about the impact of parents' engagement on the study's outcomes cannot be drawn in this case as the article does not report on many of the secondary outcome measures of interest cited in the original protocol (e.g. accessibility, availability, family barriers to FV, etc.) (Thompson et al., 2012).

Active Video Gaming. Two studies investigated Active Video Gaming (AVG) as a means of weight management. Maddison, Jull, Marsh, Dieito and Mhurchu (2013) recruited 
adolescents with overweight or obesity. Participants in the IG reported lower snack consumption but the difference from the CG was not significant. IG participants also reported lower sedentary screentime; these reports were supported by larger decreases in BMI and BMI z-scores among this group (IG BMI difference $=-0.24 \mathrm{~kg} / \mathrm{m}^{2}, \mathrm{IG}$ BMI z-score difference $=-0.06)$.

In a second, similar study (Simons et al., 2015) (also drawing on SDT and the Theory of Planned Behaviour), IG participants reported lower snack consumption than those in the CG; again, the difference was not significant. IG participants also reported lower sedentary screentime and reduced non-active video gaming. Conversely, this study found that CG participants had a greater reduction in BMI-SDS than IG participants (difference $=0.13, \mathrm{NS})$; the authors attribute the discrepancy to social desirability bias in self-report responses. A process evaluation provided valuable insight into the reasons for participant engagement; the authors found that $25 \%$ of the IG did not engage with the active games at all, and noted that enjoyment of the games decreased over time while agreement with the statement 'I'd rather play non-active video games' increased. This suggests that AVG is unlikely, in its current form, to be a broadly-effective weight management tool. However, half of the process evaluation respondents stated their intention to continue using AVG beyond study completion, suggesting that enjoyment was high for some. Despite the mixed findings, the authors suggest that AVG might prove effective among adolescents at risk or already obese (as in Maddison et al.'s, 2013, study) or among less 'excessive' gamers (participants spent > 13 hours per week playing games at baseline), or with a higher 'treatment dose' (i.e. more time on AVG). Given the 'popularity of video gaming among youth', the authors conclude that further research is needed to bring AVGs in line with non-AVGs in terms of fun, attractiveness and sustainability. On the basis of current evidence, however, reduction in snacking is unlikely to underpin the efficacy of AVGs. 
mHealth

Mobile health, often referred to as 'mHealth' is defined as 'medical health practice supported by mobile devices' (e.g. mobile phones, tablets and other wireless technology) (WHO, 2017). Mobile devices are increasingly common in both the developing and developed world, providing an opportunity to deliver convenient and innovative health behaviour change interventions to a wide audience. Seven studies of this kind were identified for the review. Table 1 summarises these studies' characteristics, while Table 6 provides details of individual studies. 
Table 6: mHealth intervention study characteristics

\begin{tabular}{|c|c|c|c|c|c|c|c|}
\hline \multicolumn{7}{|c|}{ mHealth interventions } & \multirow[b]{2}{*}{$\begin{array}{l}\text { Theoretical } \\
\text { framework }\end{array}$} \\
\hline Authors & Year & $\begin{array}{l}\text { mHealth } \\
\text { type } \\
\text { (intervention } \\
\text { length) }\end{array}$ & $\begin{array}{l}\text { Target of } \\
\text { intervention }\end{array}$ & $\begin{array}{l}\text { Primary outcome } \\
\text { (measure)* }\end{array}$ & $\begin{array}{l}\text { Statistically significant difference } \\
\text { shown on primary outcome } \\
\text { immediate IPI? }\end{array}$ & $\begin{array}{l}\text { Statistically } \\
\text { significant } \\
\text { difference shown at } \\
\text { LTFU? (LTFU } \\
\text { period) }\end{array}$ & \\
\hline $\begin{array}{l}\text { Byrd- } \\
\text { Bredbenner } \\
\text { et al. }\end{array}$ & 2018 & $\begin{array}{l}\text { Website } \\
(12 \text { months })\end{array}$ & $\begin{array}{l}\text { Healthy } \\
\text { home } \\
\text { environment }\end{array}$ & $\begin{array}{l}\text { Household food availability } \\
\text { Food-related lifestyle } \\
\text { practices } \\
\text { (measure not named, various } \\
\text { questions related to FMF, } \\
\text { FV availability etc.) }\end{array}$ & No & No LTFU & $\begin{array}{l}\text { SCT; } \\
\text { Social ecological } \\
\text { model }\end{array}$ \\
\hline $\begin{array}{l}\text { Carfora et } \\
\text { al. }\end{array}$ & 2016 & $\begin{array}{l}\text { SMS text } \\
\text { message }(x \\
14) \\
(2 \text { weeks })\end{array}$ & $\begin{array}{l}\text { Adolescent } \\
\text { FV intake }\end{array}$ & $\begin{array}{l}\text { Adolescent FV intake } \\
\text { (Author-scripted q on FV } \\
\text { portions) }\end{array}$ & $\begin{array}{l}\text { Increase FV intake in both Igs as } \\
\text { compared to } C G(p=0.001 \text { for the } \\
\text { affective group and } p=0.01 \text { for the } \\
\text { instrumental group as compared to } \\
\text { CG). }\end{array}$ & No LTFU & TPB \\
\hline $\begin{array}{l}\text { Cullen et } \\
\text { al. }\end{array}$ & 2013 & $\begin{array}{l}\text { Website } \\
\text { (8 wks) }\end{array}$ & $\begin{array}{l}\text { Adolescent } \\
\text { eating } \\
\text { behaviour }\end{array}$ & $\begin{array}{l}\text { FV intake } \\
\text { (Youth Risk Behavior } \\
\text { Survey) }\end{array}$ & $\begin{array}{l}\text { More IG participants reported } \\
\text { consuming } 3 \text { or more FV portions } \\
\text { than } \mathrm{CG}(\mathrm{p}<0.01) \text {, but not } 5 \text { or more }\end{array}$ & No LTFU & SCT \\
\hline $\begin{array}{l}\text { Cullen et } \\
\text { al. }\end{array}$ & 2017 & $\begin{array}{l}\text { Website } \\
\text { (8 wks) }\end{array}$ & $\begin{array}{l}\text { Home food } \\
\text { environment } \\
\& \text { dietary } \\
\text { behaviour }\end{array}$ & $\begin{array}{l}\text { Availability of FV and } \\
\text { high/low fat foods } \\
\text { (author-scripted } \\
\text { questionnaire) } \\
\text { Child FV intake } \\
\text { (Youth Risk Behaviour } \\
\text { Survey) }\end{array}$ & No & No $(4 \mathrm{~m})$ & Not stated \\
\hline $\begin{array}{l}\text { Knowlden } \\
\text { et al. }\end{array}$ & 2015 & $\begin{array}{l}\text { Website } \\
\text { (4 wks) }\end{array}$ & $\begin{array}{l}\text { Childhood } \\
\text { obesity } \\
\text { prevention }\end{array}$ & $\begin{array}{l}\text { Child FV intake } \\
\text { (scale not named but e.g. } \\
\text { questions provided) }\end{array}$ & $\begin{array}{l}\text { IG increased FV consumption } \\
\text { relative to } C G(p=0.036)\end{array}$ & $\begin{array}{l}\text { IG increased FV } \\
\text { consumption } \\
(\mathrm{p}<0.001)(12 \mathrm{~m})\end{array}$ & SCT \\
\hline $\begin{array}{l}\text { Nystrom et } \\
\text { al. }\end{array}$ & 2015 & $\begin{array}{l}\text { App } \\
\text { (6 months) }\end{array}$ & $\begin{array}{l}\text { Childhood } \\
\text { obesity } \\
\text { prevention }\end{array}$ & $\begin{array}{l}\text { Body fat } \\
\text { (Fat Mass Index, FMI) }\end{array}$ & No & No LTFU & SCT \\
\hline
\end{tabular}




\begin{tabular}{|l|l|l|l|l|l|l|l|}
\hline \multicolumn{9}{|c|}{ mHealth interventions } & $\begin{array}{l}\text { Statistically significant difference } \\
\text { shown on primary outcome } \\
\text { immediate IPI? }\end{array}$ & $\begin{array}{l}\text { Statistically } \\
\text { significant } \\
\text { difference shown at } \\
\text { LTFU? (LTFU } \\
\text { period) }\end{array}$ & $\begin{array}{l}\text { Theoretical } \\
\text { framework }\end{array}$ \\
\hline Authors & Year & $\begin{array}{l}\text { mHealth } \\
\text { type } \\
\text { (intervention } \\
\text { length) }\end{array}$ & $\begin{array}{l}\text { Target of } \\
\text { intervention }\end{array}$ & $\begin{array}{l}\text { Primary outcome } \\
\text { (measure* }\end{array}$ & No (6m) & $\begin{array}{l}\text { Information } \\
\text { Behaviour Model }\end{array}$ \\
\hline Sun et al. & 2017 & $\begin{array}{l}\text { Tablet } \\
\text { computer- } \\
\text { based } \\
(8 \mathrm{wks})\end{array}$ & $\begin{array}{l}\text { Childhood } \\
\text { obesity } \\
\text { prevention }\end{array}$ & Child BMI & No & \\
\hline
\end{tabular}

IPI = Immediately post-intervention

*If a PO is not explicitly stated in the study, it is selected according to the aims \& objectives of the study. Where the study involves other health behaviours, the primary eating outcome $\&$ behaviour have been selected.

$\mathrm{NR}=$ not reported

SCT $=$ Social Cognitive Theory

TPB $=$ Theory of Planned Behaviour 
MINISTOP (Nyström et al., 2017) is a smartphone application (app) delivered to parents and designed to prevent obesity in pre-schoolers drawing on Social Cognitive Theory (SCT). The app delivers information, tips and strategies on 12 topics (e.g. healthy foods, breakfast, physical activity), with prompts if parents fail to access the app regularly. It provides weekly graphical feedback based on information provided by parents and, if required, support from a dietician and/or psychologist. Alongside traditional parent-report measures, the study used novel methods of data collection (such as the Tool for Energy Balance in Children, (TECH), Delisle et al., 2015), which estimates dietary intake from photographs of meals taken by parents. Body fatness (Fat Mass Index, FMI) was measured, rather than BMI; the authors suggest that BMI is a poor indicator of body fat. The intervention had no effect on FMI alone, but IG participants increased their 'composite component score' (a summation of FMI, FV intake, sweet intake, sugar-sweetened beverage intake, sedentary time and moderate to vigorous physical activity). Although FMI was the primary outcome measure, the composite score was arguably the more important outcome, given that the study was an obesity prevention intervention that recruited children of normal weight (mean weight for age $\mathrm{z}$-score was $0+/-1.16$ at baseline). Interestingly, the study actively accommodated separated parents, allowing both to participate. The study maintained high levels of engagement (with no report of incentives for retention) and produced promising results. Future work should consider whether FMI is the appropriate primary outcome measure for similar interventions and why this showed no change.

Teen Choice: Food \& Fitness is a website designed to promote healthy eating and physical activity in adolescents, also using SCT as a theoretical framework (Cullen, Thompson, Boushey, Konzelman \& Chen., 2013). Twelve- to 17-year-olds were randomly allocated to receive details of the intervention website, containing materials about nutrition and physical activity, goal setting, a healthy eating calculator, 12 model video stories, recipes and a blog, 
or to receive details of a similar control website. The IG reported an increase in daily vegetable consumption of more than 3 portions, but there was no between-group difference in the numbers achieving at least 5 daily portions of FV. Both groups reduced their television viewing and increased their physical activity to at least 60 minutes per day. This study addressed the problem of social desirability in self-report measures by collecting an independent index of social desirability and entering this as a covariate in analyses. Nevertheless, questions remain over the reliability of young people's self-reports. This study also had a self-selecting sample and a control condition in which several elements were identical to the intervention, making it difficult to ascertain which of the study's findings might generalize to a wider sample.

Also grounded in SCT is EMPOWER (Knowlden, Sharma, Cottrell, Wilson, \& Johnson, 2015) a web-based intervention which aims to support mothers' self-development across several constructs: environment, emotional coping, expectations, self-control and selfefficacy. The intervention was expected to lead to positive outcomes for children including increased physical activity and FV consumption and decreased sugar-free beverage consumption and screentime. The study had an active-control group who participated in 5 knowledge-based (rather than theory-based) 'educational sessions'. Immediately postintervention and at a 4-week follow up, both groups showed significant improvements in physical activity, sugar-free beverage intake and screentime (with no between-group differences) but only the IG showed an improvement in FV intake. At a 1-year follow-up (Knowlden \& Sharma, 2016), this effect remained in the IG, equating to an increase of 1.8 cups of FV per day; all other significant effects had disappeared. The targeted maternal SCT constructs accounted for $33 \%$ and $13 \%$ of the change in FV consumption in the IG at the two follow-up time points, respectively. The authors provide a detailed theoretical rationale for the EMPOWER intervention and achieved a considerable increase in FV consumption, with a 
methodology that is practicable to roll out to a wider group. However, results should be treated with caution as F and V are not treated separately and may, therefore, be driven solely by increases in fruit consumption. It is also unfortunate that, despite the several published papers about the intervention, little detail is provided regarding its content, inhibiting the development of similar interventions.

The HomeStyles (Byrd-Bredbenner et al., 2018) program is a web-based intervention designed to help parents 'make quick, easy, no-cost changes to their home environment...to support child growth and avoid childhood obesity' (p.140). The intervention content extracts from SCT, while 'adult learning theory' and 'motivational interviewing' are employed as learning techniques for participants, Spanish- and English-speaking parents of 2- to 6-yearolds were invited to select among modules that focussed on nutrition, physical activity, sleep and advocacy, which were delivered over 12 months. CG participants engaged with a website with an identical format but with content focussing on safety in the home. No changes in dietary intake were observed in either group immediately post-intervention. Long-term follow-up outcomes are still to be reported. Data collection occurred online and, as is often the case with web-based studies, retention rates were low (35\% post-intervention), despite the authors' notable efforts to reduce attrition.

Carfora, Caso, and Conner (2016) conducted a randomised controlled trial to assess the efficacy of text messages sent to adolescents at increasing FV intake and drew on the Theory of Planned Behaviour in their design. Messages were either 'instrumental' (e.g. 'a diet rich in fruits and vegetables promote [sic] emotional well-being being associated with a lower prevalence of anxiety and depression') or 'affective' (e.g. 'a diet rich in vegetable and fruit reduces by $30-40 \%$ the probability of contracting cancer'). CG participants received no messages. The messages provoked a larger increase in FV consumption in both IGs (>1 
portion per day) compared to the $\mathrm{CG}$, with larger effects for affective messages. No longterm follow-up data is provided. Again, little detail is provided regarding the text message contents, which appear to be long and potentially disengaging for teenagers, and no formative or evaluative work is reported regarding feasibility or acceptability. The authors also point out that messages were not exclusively instrumental or affective and that affective messages tended to focus on the short-term outcomes of FV consumption, suggesting alternative psychological explanations for the behaviour change seen in that group. Nevertheless, the relatively large effect sizes suggest that a more carefully designed RCT with longer-term outcome measures might be fruitful.

Family Eats (Cullen, Thompson \& Chen, 2017) is a web-based program targeting the home food environment and dietary behaviour of parents and children aged 8 to 12 years. It comprises 8 weekly online 'sessions' including graphics that tell the story of a family trying to develop healthier eating habits, tip sheets and recipes. Formative work in intervention development took place but no theoretical framework is explicitly described. The CG had access to the same website without the graphics. There were no between-group differences in FV consumption either post-intervention or 4 months later. Some positive changes were reported by the IG group alone (e.g. increased juice availability), but many were demonstrated in both groups (e.g. increased fruit availability). Strengths of the study include the recruitment of a more disadvantaged participant group than is typical and the positive feedback and evaluation provided by participants, reflected in a relatively high retention rate (68\%). Given the high degree of overlap between the IG and CG intervention materials, further research would be necessary to better unpick the more effective elements of the intervention. 
Sun et al. (2017) evaluated a tablet-based intervention that aimed to prevent obesity in American-Chinese mothers with children aged 3 to 5 years old. Its theoretical framework was described as being based on the 'Information-Motivation Behaviour Model' (Fisher, Fisher \& Harman, 2003). The intervention consisted of animated short videos, including two in 'talkshow' format', and children's songs, re-worded to fit the intervention. The CG received weekly mailings of printed health information. It is unclear whether the primary targets of this study were mothers, children, or both; results showed that more IG mothers had reduced BMI six months post-intervention but no group difference for child BMI.

\section{Other equipment}

One study (Galhardo et al., 2012) did not fit neatly into other categories but remained within the scope of our review. This evaluated the use of a Mandometer in the home for children and adolescents with obesity (BMI SDS $\geq 95^{\text {th }}$ centile, $9-18$ years old). The Mandometer is a machine that is sometimes used to treat eating disorders; it provides the user with feedback about their eating rate, based on plate weight, and can be used to achieve an 'ideal eating speed'. It was hypothesised that, by slowing eating rates and inducing postprandial suppression of ghrelin, the IG would show increased weight loss. As predicted, the IG showed significant decreases in BMI-SDS, percent body fat, meal portion size, glucose and fasting ghrelin, while the $\mathrm{CG}$ did not. The study had a very small sample (N=27) but nevertheless showed promising results in a clinical population. Cost-effectiveness was not addressed and may prove an obstacle to wider implementation. However, smartphone apps have been designed that provide a similar service; further research could explore their effectiveness in this population. 


\section{Synthesis of Literature and Conclusions for Future Research and Application}

This review set out to describe and evaluate the evidence relating to home-based family eating interventions and to establish the elements of such interventions that might lead to successful behaviour change. The following section synthesises the key findings of the literature reviewed, first drawing out the characteristics of successful and unsuccessful interventions in terms of both their design and implementation and their basis in theory or evidence, and second highlighting the methodological limitations of the studies reviewed and making recommendations for how these should be addressed in future research.

\section{Characteristics of successful and unsuccessful interventions}

Most of the studies that reported follow-up data collected six months or more after intervention delivery did not find significant long-term behaviour change; effect sizes, where reported, were small. One notable exception is the EMPOWER study (Knowlden \& Sharma, 2016), a theory driven, web-based intervention which showed an increase in consumption of FV of almost two cups per day, 12 months post-intervention. This study reflects a broad trend for interventions based on theory to result more often in significant behaviour change, as we discuss in the next section.

\section{Basis in theory and evidence}

In total, six studies (Pearson et al., 2010, Baranowski et al., 2011, Wyse et al., 2012, Corsini et al., 2013, Knowlden et al., 2015, Thompson et al., 2015) showed some behaviour change in an IG compared to a CG beyond immediate post-intervention data collection (see tables 2 -6). All but one provided theoretical rationale, with the majority focussing on Social Cognitive Theory (SCT) and/or similar principles (in the case of Wyse et al., the authors did not cite SCT but did refer to a socio-ecological framework). This collection of studies appears to be set apart from the many others in the review referring to SCT in that authors 
went into noticeably more theoretical detail and attempted to integrate the principles of SCT with other theories (e.g. Self-Determination Theory, Behavioural Choice Theory, maintenance theories and Golan et al.'s 2001 Familial Model). The remaining study with longer term success (Corsini et al., 2013) took a more experimental approach and was rooted in the evidence base surrounding exposure.

There is an important distinction between no change at follow-up and no evidence of change at follow-up due to lack of data. Given the high number of studies which did not conduct any follow up beyond the end of the intervention, we also examined the characteristics of interventions with significant results immediately post-intervention where the study did not collect LTFU data. Of the studies that reported no LTFU, 12 reported significant betweengroups differences on their primary eating-related outcome measure immediately postintervention (Wardle et al., 2003, Rodearmal et al., 2006, Haire-Joshu et al., 2008, Cullen et al., 2013, McGowan et al., 2013, Wieland et al., 2013, Makert et al., 2014, Heath et al., 2014, Cravener et al., 2015, Leung et al., 2015, Carfora et al., 2016, Wrieden \& Levy., 2016) . Half of these studies reported a theoretical rationale. These interventions warrant further investigation to establish whether longer-term behaviour change can be achieved.

Careful analysis showed no systematic similarities shared by the short-term successful interventions. Studies drawing on exposure as a mechanism to encourage FV consumption appeared to show promise collectively. However, all but one lacked long-term follow-up of the observed behaviour changes, and some reported that parents found repeated exposure to be burdensome. Future research might seek to identify more natural implementations of exposure-based interventions in the family home; novel methods of exposure (such as picture books, Houston-Price, Owen, Kennedy \& Hill, 2019) might be easier for parents.

\section{Methodological factors}


The six studies that did demonstrate longer-term behaviour change represented a range of delivery methods (the collection comprised one of each of home visit, telephone, printed information and mHealth, and two video-game studies), suggesting that all of these methods could feasibly lead to behaviour change. However, when examining the wider collection of studies described above (i.e. short-term behaviour change but no long-term follow-up), interventions that were person-delivered (i.e. involved human contact either face-to-face or over the telephone) were noticeably more likely to result in behaviour change than those which were information-delivered. Within the person-delivered category, however, studies in which a 'peer educator' delivered the intervention resulted in less success than those delivered by a researcher or health professional.

Information/technology-delivered interventions were less successful. Those that involved printed material and mHealth interventions were least likely to result in behaviour change. Both suffered from high attrition rates; the absence of the encouragement of a researcher or health professional may have reduced participants' motivation or willingness to continue. The information-based content of these types of intervention might also be off-putting or unengaging. Alternatively, most parents may already have reasonable knowledge of what constitutes healthy foods for children (Hart, Damiano, Cornell, \& Paxton, 2015), and therefore benefit little from receiving further similar information. Parents may be less aware of the influence of their own feeding practices on children's behaviour, however. For example, in the motivational interviewing study (Tabak et al., 2012), no parents chose intervention elements that tackled their own behaviour at mealtimes (i.e. modelling and family meal frequency). Parents might not see the need to change their own feeding practices or might perceive this to be more difficult than tackling their child's eating. Future research should therefore consider parents' understanding of their role in shaping children's eating behaviours. 
It is noteworthy that the number of mHealth interventions (and published protocols) included in the review doubled when the search was re-run in early 2018; this research area is evidently expanding rapidly despite the failures of early studies. Although current evidence indicates that the more intense interventions delivered through home-visits and telephone may be necessary to invoke meaningful behaviour change, the success of the EMPOWER study suggests mHealth may have the power to change behaviour with extensive formative work. More informed development could lead to improved outcomes for this type of intervention.

The majority of studies aimed to change parental behaviour, although those interventions targeting adolescent eating behaviour were more likely to involve active participation from the child. This is in line with evidence that suggests parents are the agent of change for younger but not teenage children (Golan, 2006, McLean et al., 2003). Several studies were based on the concept that parents' behaviour change might mediate the relationship between interventions and children's behaviour change (e.g. Wyse et al., 2014). This is a sensible assumption; if parents are responsible for making healthy food available and accessible, their engagement in a healthy eating intervention alongside the child is likely to be beneficial. It is interesting to note that one of the few printed materials studies to induce higher FV consumption in the IG was unique in targeting children and adults separately (Pearson et al., 2010), while an unsuccessful printed information study highlighted the confusion about which family members their intervention was targeting (Croker et al., 2012). It is surprising, then, that most interventions focus on the child or parent alone, or adopt a 'one size fits all' approach. Consideration should be given to the target participants within family interventions. 


\section{Weaknesses of the literature reviewed}

The variation in the length of follow-up periods across the studies in this review renders it impossible to compare the interventions' long-term efficacy. Many studies did not identify their primary outcome measures a priori, instead leading their results sections with significant findings, regardless of whether these related to the aims and objectives set out in the title and introduction. Some studies included numerous outcome measures, making the chance of Type 1 errors higher.

There was also little consistency in the selected outcome measures, even though studies often aimed for the same outcomes. For example, BMI, BMI-SDS, BMI z scores and Fat Mass Index were all used as indices of weight loss/gain in different studies. This inconsistency makes comparison between findings difficult, and meta-analysis impossible. Another difficulty specific to the interpretation of BMI outcome data is that several 'obesity prevention' studies interpreted a lower BMI in the IG than in the CG as a success, even for those within the healthy range. Arguably, it would be more meaningful to examine those in each group whose BMI is outside the healthy range, for example, by investigating whether overweight individuals' BMI reduced as a result of intervention, or whether the proportion of participants with a healthy BMI score increased post-intervention. Outcome measures should also reflect the target of the intervention; for example, obesity prevention studies involving healthy weight individuals might examine the proportion of participants who enter an unhealthy BMI category, while obesity reduction studies might be more concerned with absolute weight loss.

FV intake was similarly measured using a variety of scales. Only a handful of studies considered fruit intake and vegetable intake separately. As several studies suggest that fruit intake may be easier to increase, the two food types should be measured separately; 
otherwise, apparently successful interventions reporting increased FV intake might solely reflect changes in fruit intake.

Most behavioural measures were collected using self-report instruments, not all of which had been validated. Although self-report is widely used for collecting dietary data, its reliability is questioned, particularly when obtained from children or adolescents (Walker, Ardouin \& Burrows, 2017). Guidelines exist to improve the reliability of such measures (e.g. comparing parents' and children's reports; biochemical validation; see Subar et al. 2015); no study included in this review reported following these guidelines. Some findings collected from children seem implausible (Markert et al., 2014), indicating the possibility of a more widespread problem with self-report measures in this population.

People from more advantaged backgrounds and higher socio-economic status are more likely to display healthier eating habits (Pampel, Krueger \& Denney, 2010). Healthy eating interventions typically aim to reduce such health inequalities, by recruiting participants from more disadvantaged backgrounds. While most studies in this review attempted to recruit participants from disadvantaged or at-risk groups, many authors were open about the difficulties they encountered in doing so. Most studies relied on self-selecting samples; those providing information on non-completers noted that those on lower incomes were more likely to withdraw (e.g. Leung et al. 2015). The challenge to recruit 'those who really need it' to interventions merits attention.

\section{Analyses}

A notable inconsistency related to authors' use of Intention to Treat (ITT) analyses versus Per Protocol Analyses (PPA) or 'all available data'. Although ITT is considered 'gold-standard' in health research (see Armijo-Olivo, Warren \& Magee, 2009), the majority of studies did not employ this method. Printed materials and mHealth interventions were most likely to follow 
PPA, perhaps reflecting the much lower retention rates in these studies. This may be a sensible approach, however, depending on the intervention's cost. If an intervention is cheap to roll out to a wide audience, engages only a small subgroup of participants but leads to significant behaviour change within the participating group, there is a strong rationale to pursue the intervention. If, on the other hand, an intervention is costly and engages only a small number of people with a small effect size, the case for supporting it is less convincing. Future assessments of interventions in relation to their cost and effect size, as well as their retention rates, could therefore be fruitful.

\section{Financial cost of interventions}

Few studies discussed the cost of their intervention or its further development. Only one study attempted a cost-effectiveness analysis, which has yet to be published (Wen et al., 2012). Setting development costs aside, home visits and other person-delivered interventions are likely to be very expensive to deliver on a large scale (Rudolf, 2012), unless they can be incorporated into a pre-existing home visit programme. Technology-delivered interventions vary in their costs. While web-based interventions reach large audiences quickly, conveniently and inexpensively, smartphone/ tablet applications are very expensive to maintain (Bartle, Wallace \& Curtis, 2015). If difficulties around engagement can be overcome, carefully-designed web-based interventions may therefore play an important role in the future of family eating interventions.

\section{Conclusions}

Changing healthy eating behaviour within the family home is challenging. Successful interventions tend to have a robust theory-driven evidence-base, are based on carefullydesigned formative work and deliver engaging content. Furthermore, they have clear objectives with a well-defined target population. Future studies should address the difficulties 
around recruiting participants from disadvantaged backgrounds, demonstrate a better understanding of cost implications, and take a more consistent approach to measurement and analysis to allow intervention effects to be compared.

\section{Acknowledgements}

Thanks to Adam Edge, Romany Murray, Hannah Powlesland, Orla Brown and Ella Lindley for assisting with this review.

This research was conducted as part of an ESRC SEDTC funded studentship in partnership with the online parenting organisation Netmums.

There are no conflicts of interest to declare.

\section{References}

Ackard, D. M., \& Neumark-Sztainer, D. (2001). Family mealtime while growing up: associations with symptoms of bulimia nervosa. Eat Disord, 9(3), pp. 239-249. doi:10.1080/10640260127551

Ajzen, I. (1991). The theory of planned behavior. Organizational Behavior and Human Decision Processes, 50(2), pp. 179-211. doi:https://doi.org/10.1016/07495978(91)90020-T

Alff, F., Markert, J., Zschaler, S., Gausche, R., Kiess, W., \& Bluher, S. (2012). Reasons for (non)participating in a telephone-based intervention program for families with overweight children. PLoS One, 7(4), p e34580. doi:10.1371/journal.pone.0034580

Anzman-Frasca, S., Savage, J. S., Marini, M. E., Fisher, J. O., \& Birch, L. L. (2012). Repeated exposure and associative conditioning promote preschool children's liking of vegetables. Appetite, 58(2), pp. 543-553. doi:10.1016/j.appet.2011.11.012

Armijo-Olivo, S., Warren, S., \& Magee, D. (2009). Intention to treat analysis, compliance, drop-outs and how to deal with missing data in clinical research: a review. Physical Therapy Reviews, 14(1), pp. 36-49. doi:10.1179/174328809X405928 
Bandura, A. (1986). Social foundations of thought and action: A Social Cognitive Theory Englewood Cliffs NJ: Prentice-Hall.

Baranowski, T., Baranowski, J., Cullen, K. W., Marsh, T., Islam, N., Zakeri, I., . . . deMoor, C. (2003). Squire's Quest! Dietary outcome evaluation of a multimedia game. Am J Prev Med, 24(1), pp. 52-61.

Bartle, N., Wallace, L. \& Curtis, K. (2015). Realising the potential for delivering health psychology interventions via smartphone 'apps': Consideration of equity, effectiveness and implementation. Health Psychology Update, 24(1), pp. 16-22.

Beale, D. A., \& Manstead, A. S. R. (1991). Predicting Mothers' Intentions to Limit Frequency of Infants' Sugar Intake: Testing the Theory of Planned Behavior1. Journal of Applied Social Psychology, 21(5), pp. 409-431. doi:doi:10.1111/j.1559-1816.1991.tb00528.x

Becker, M. (1974). The Health Belief Model and Personal Health Behavior. Health Education Monographs(2), pp. 324-508.

Berge, J. M., Loth, K., Hanson, C., Croll-Lampert, J., \& Neumark-Sztainer, D. (2012). Family life cycle transitions and the onset of eating disorders: A retrospective grounded theory approach. Journal of Clinical Nursing, 21(9-10), pp. 1355-1363.

Blanchette, L., \& Brug, J. (2005). Determinants of fruit and vegetable consumption among 612-year-old children and effective interventions to increase consumption. J Hum Nutr Diet, 18(6), pp. 431-443. doi:10.1111/j.1365-277X.2005.00648.x

Bleich, S. N., Segal, J., Wu, Y., Wilson, R., \& Wang, Y. (2013). Systematic review of community-based childhood obesity prevention studies. Pediatrics, 132(1), pp. e201210. doi:10.1542/peds.2013-0886

Branca, F., Piwoz, E., Schultink, W., \& Sullivan, L. M. (2015). Nutrition and health in women, children, and adolescent girls. [10.1136/bmj.h4173]. BMJ : British Medical Journal, 351

Brazilian Ministry of Health. (2002). Ten Steps for Healthy Feeding In Ministry of Health/Pab American of Health (Ed.). Brazil. 
Byrd-Bredbenner, C., Martin-Biggers, J., Povis, G. A., Worobey, J., Hongu, N., \& Quick, V. (2018). Promoting healthy home environments and lifestyles in families with preschool children: HomeStyles, a randomized controlled trial. Contemporary Clinical Trials, 64, pp. 139-151. doi:10.1016/j.cct.2017.10.012

Campbell, M., Fitzpatrick, R., Haines, A., Kinmonth, A. L., Sandercock, P., Spiegelhalter, D., \& Tyrer, P. (2000). Framework for design and evaluation of complex interventions to improve health. BMJ, 321(7262), pp. 694-696. doi:10.1136/bmj.321.7262.694

Campbell, K. J., \& Hesketh, K. D. (2007). Strategies which aim to positively impact on weight, physical activity, diet and sedentary behaviours in children from zero to five years. A systematic review of the literature. Obes Rev, 8(4), pp. 327-338. doi:10.1111/j.1467-789X.2006.00305.X

Carfora, V., Caso, D., \& Conner, M. (2016). Randomized controlled trial of a messaging intervention to increase fruit and vegetable intake in adolescents: Affective versus instrumental messages. Br J Health Psychol, 21(4), pp. 937-955. doi:10.1111/bjhp.12208

Carruth, B. R., \& Skinner, J. D. (2000). Revisiting the picky eater phenomenon: neophobic behaviors of young children. J Am Coll Nutr, 19(6), pp. 771-780.

Change4Life. (2015). About Change4Life. Retrieved $2^{\text {nd }}$ February 2018 from http://www.nhs.uk/Change4Life/Pages/why-change-for-life.aspx.

Centre for Reviews and Dessemination (2009). Systematic Reviews: CRD's guidance for undertaking reviews in health care York, UK: York Publishing Services Ltd.

Corsini, N., Slater, A., Harrison, A., Cooke, L., \& Cox, D. N. (2013). Rewards can be used effectively with repeated exposure to increase liking of vegetables in 4-6-year-old children. Public Health Nutr, 16(5), pp. 942-951. doi:10.1017/s1368980011002035 
Cravener, T. L., Schlechter, H., Loeb, K. L., Radnitz, C., Schwartz, M., Zucker, N., . . Keller, K. L. (2015). Feeding Strategies Derived from Behavioral Economics and Psychology Can Increase Vegetable Intake in Children as Part of a Home-Based Intervention: Results of a Pilot Study. J Acad Nutr Diet, 115(11), pp. 1798-1807. doi:10.1016/j.jand.2015.03.024

Crespo, N. C., Elder, J. P., Ayala, G. X., Slymen, D. J., Campbell, N. R., \& Sallis, J. F. (2012). Results of a multi-level intervention to prevent and control childhood obesity among Latino children: The Aventuras Para Ninos Study. Ann Behav Med, 43doi:10.1007/s12160-011-9332-7

Croker, H., Lucas, R., \& Wardle, J. (2012). Cluster-randomised trial to evaluate the 'Change for Life' mass media/ social marketing campaign in the UK. BMC Public Health, 12, p 404. doi:10.1186/1471-2458-12-404

Cullen, K. W., Thompson, D., Boushey, C., Konzelmann, K., \& Chen, T.-A. (2013). Evaluation of a web-based program promoting healthy eating and physical activity for adolescents: Teen Choice: Food and Fitness. Health Education Research, 28(4), pp. 704-714.

Cullen, K. W., Thompson, D., \& Chen, T.-A. (2017). Outcome Evaluation of Family Eats: An Eight-Session Web-Based Program Promoting Healthy Home Food Environments and Dietary Behaviours for African American Families. American Journal of Health Behavior, 32(1), pp. 40-51.

Deci, E. R., R. (2012). Self-determination theory. In P. Van Lange, Kruglanski, A \& Higgins, E. (Ed.), Handbook of Theories of Social Psychology: Collection: Volumes 1 \& 2 (pp. 349-374). London: SAGE. 
Delisle, C., Sandin, S., Forsum, E., Henriksson, H., Trolle-Lagerros, Y., Larsson, C., . . Lof, M. (2015). A web- and mobile phone-based intervention to prevent obesity in 4-yearolds (MINISTOP): a population-based randomized controlled trial. BMC Public Health, 15, p 95. doi:10.1186/s12889-015-1444-8

Dennison, B. A., Rockwell, H. L., \& Baker, S. L. (1998). Fruit and Vegetable Intake in Young Children. Journal of the American College of Nutrition, 17(4), pp. 371-378. doi:10.1080/07315724.1998.10718778

Deshpande, S., Basil, M. D., \& Basil, D. Z. (2009). Factors influencing healthy eating habits among college students: an application of the health belief model. Health Mark $Q$, 26(2), pp. 145-164. doi:10.1080/07359680802619834 Retrieved from http://www.ncbi.nlm.nih.gov/pubmed/19408181

Dickens, E., \& Ogden, J. (2014). The role of parental control and modelling in predicting a child's diet and relationship with food after they leave home. A prospective study. Appetite, 76, pp. 23-29. doi:10.1016/j.appet.2014.01.013

Dwyer, L., Oh, A., Patrick, H., \& Hennessy, E. (2015). Promoting family meals: a review of existing interventions and opportunities for future research. Adolesc Health Med Ther, 6, pp. 115-131. doi:10.2147/ahmt.s37316

Estabrooks, P. A., Shoup, J. A., Gattshall, M., Dandamudi, P., Shetterly, S., \& Xu, S. (2009). Automated telephone counseling for parents of overweight children: A randomized controlled trial. American Journal of Preventive Medicine, 36(1), pp. 35-42.

Evans, C. E., Christian, M. S., Cleghorn, C. L., Greenwood, D. C., \& Cade, J. E. (2012). Systematic review and meta-analysis of school-based interventions to improve daily fruit and vegetable intake in children aged 5 to 12 y. Am J Clin Nutr, 96(4), pp. 889901. doi:10.3945/ajen.111.030270

Fisher, W., Fisher, J \& Harman, J. (2003). The Information Motivation Behavioural Skills Model:A general social psychological approach to understanding and promoting 
health behavior In J. W. Suls, K (Ed.), Social Psychological Foundations of Health and Illness (pp. 82-103). Cornwall, UK: Wiley.

Fulkerson, J. A., Kubik, M. Y., Rydell, S., Boutelle, K. N., Garwick, A., \& Story, M. (2011). Focus groups with working parents of school-aged children: what's needed to improve family meals? J Nutr Educ Behav, 43doi:10.1016/j.jneb.2010.03.006 Retrieved from http://dx.doi.org/10.1016/j.jneb.2010.03.006

Galhardo, J., Hunt, L. P., Lightman, S. L., Sabin, M. A., Bergh, C., Sodersten, P., \& Shield, J. P. (2012). Normalizing eating behavior reduces body weight and improves gastrointestinal hormonal secretion in obese adolescents. J Clin Endocrinol Metab, 97(2), pp. E193-201. doi:10.1210/jc.2011-1999

Gardner, B., Sheals, K., Wardle, J., \& McGowan, L. (2014). Putting habit into practice, and practice into habit: a process evaluation and exploration of the acceptability of a habit-based dietary behaviour change intervention. International Journal of Behavioral Nutrition and Physical Activity, 11(1), p 135. doi:10.1186/s12966-014$0135-7$

Gholami, M., Wiedemann, A., Knoll, N., \& Schwarzer, R. (2015). Mothers improve their daughters' vegetable intake: A randomized controlled trial. Psychology, Health \& Medicine, 20(1), pp. 1-7.

Gillis, L. \& Gillis, A. (2005). Nutrition inadequacy in obese and non-obese youth. Canadian Hournal of Dietetic Practice and Research, 66 (237-242).

Gillman, M. W., Rifas-Shiman, S. L., Frazier, A. L., Rockett, H. R., Camargo, C. A., Jr., Field, A. E., . . Colditz, G. A. (2000). Family dinner and diet quality among older children and adolescents. Arch Fam Med, 9(3), pp. 235-240. 
Golan, M., \& Weizman, A. (2001). Familial Approach To The Treatment Of Childhood Obesity: Conceptual Model. Journal of Nutrition Education, 33(2), pp. 102-107. doi:10.1016/S1499-4046(06)60173-5

Golan, M. (2006). Parents as agents of change in childhood obesity--From research to practice. International Journal of Pediatric Obesity, 1(2), pp. 66-76.

Government of Canada. (2018). Let's Eat Healthy Canada. Retrieved $2^{\text {nd }}$ February 2018 from https://www.canada.ca/en/health-canada/services/publications/foodnutrition/infographic-lets-eat-healthy-canada.html.

Hardeman, W., Johnston, M., Johnston, D., Bonetti, D., Wareham, N., \& Kinmonth, A. L. (2002). Application of the Theory of Planned Behaviour in Behaviour Change Interventions: A Systematic Review. Psychology \& Health, 17(2), pp. 123-158. doi:10.1080/08870440290013644a

Hart, L. M., Damiano, S. R., Cornell, C., \& Paxton, S. J. (2015). What parents know and want to learn about healthy eating and body image in preschool children: a triangulated qualitative study with parents and Early Childhood Professionals. BMC Public Health, 15(1), p 596. doi:10.1186/s12889-015-1865-4

Hart, L. M., Damiano, S. R., \& Paxton, S. J. (2016). Confident body, confident child: A randomised controlled trial evaluation of a parenting resource for promoting healthy body image and eating patterns in 2- to 6-year old children. Int J Eat Disorddoi:10.1002/eat.22494

Haines, J., McDonald, J., O'Brien, A., Sherry, B., Bottino, C. J., \& Schmidt, M. E. (2013). Healthy Habits, Happy Homes: Randomized trial to improve household routines for obesity prevention among preschool-aged children. JAMA Pediatr, 167, pp. 10721079. doi:10.1001/jamapediatrics.2013.2356

Haire-Joshu, D., Elliott, M. B., Caito, N. M., Hessler, K., Nanney, M., Hale, N., . . Brownson, R. C. (2008). High 5 for kids: The impact of a home visiting program on 
fruit and vegetable intake of parents and their preschool children. Preventive

Medicine: An International Journal Devoted to Practice and Theory, 47(1), pp. 77-

82. doi: 10.1016/j.ypmed.2008.03.016

Harvey-Berino, J., \& Rourke, J. (2003). Obesity Prevention in Preschool Native-American Children: A Pilot Study Using Home Visiting. Obesity Research, 11(5), pp. 606-611.

Heath, P., Houston-Price, C., \& Kennedy, O. B. (2014). Let's look at leeks! Picture books increase toddlers' willingness to look at, taste and consume unfamiliar vegetables. Frontiers in Psychology, 5, p 191.

Houston-Price, C., Butler, L., \& Shiba, P. (2009). Visual exposure impacts on toddlers' willingness to taste fruits and vegetables. Appetite, 53(3), pp. 450-453. doi:https://doi.org/10.1016/j.appet.2009.08.012

Houston-Price, C., Owen, L., Kennedy, O. \& Hill, C. (2019). Parents' experiences of introducing toddlers to fruits and vegetables through repeated exposure, with and without prior visual familiarization to foods: Evidence from daily diaries. Food Quality and Preference, 71, pp.291-300. doi:https://doi.org/10.1016/j.foodqual.2018.08.003

Ioannidis, J. P. A. (2013). Implausible results in human nutrition research. BMJ : British Medical Journal, 347. doi:10.1136/bmj.f6698

Kim, S. A., Moore, L. V., Galuska, D., Wright, A. P., Harris, D., Grummer-Strawn, L. M., . . . Health Promotion, C. D. C. (2014). Vital signs: fruit and vegetable intake among children - United States, 2003-2010. MMWR. Morbidity and mortality weekly report, 63(31), pp. 671-676.

Kalat, J. W., \& Rozin, P. (1973). "Learned safety" as a mechanism in long-delay tasteaversion learning in rats. J Comp Physiol Psychol, 83(2), pp. 198-207. 
Kennedy, E;, Ohls, J., Carlson, S. \& Fleming, K., (1995). The Healthy Eating Index: Design and Applications. Journal of the American Dietetic Association, 95(10), pp. 11031108.

Knowlden, A. P., \& Sharma, M. (2012). Systematic review of family and home-based interventions targeting paediatric overweight and obesity. Obes Rev, 13(6), pp. 499508. doi:10.1111/j.1467-789X.2011.00976.x

Knowlden, A., \& Sharma, M. (2016). One-Year Efficacy Testing of Enabling Mothers to Prevent Pediatric Obesity Through Web-Based Education and Reciprocal Determinism (EMPOWER) Randomized Control Trial. Health Educ Behav, 43(1), pp. 94-106. doi:10.1177/1090198115596737

Knowlden, A. P., Sharma, M., Cottrell, R. R., Wilson, B. R., \& Johnson, M. L. (2015). Impact evaluation of Enabling Mothers to Prevent Pediatric Obesity through WebBased Education and Reciprocal Determinism (EMPOWER) randomized control trial. Health Education \& Behavior, 42(2), pp. 171-184.

Lindsay, A. C., Sussner, K. M., Greaney, M. L., \& Peterson, K. E. (2011). Latina mothers' beliefs and practices related to weight status, feeding, and the development of child overweight. Public Health Nursing, 28(2), pp. 107-118.

Ling, J., Robbins, L. B., \& Wen, F. (2016). Interventions to prevent and manage overweight or obesity in preschool children: A systematic review. Int J Nurs Stud, 53, pp. 270289. doi:10.1016/j.ijnurstu.2015.10.017

Looney, S. M., \& Raynor, H. A. (2014). Examining the effect of three low-intensity pediatric obesity interventions: a pilot randomized controlled trial. Clin Pediatr (Phila), 53(14), pp. 1367-1374. doi:10.1177/0009922814541803 
Maddison, R., Jull, A., Marsh, S., Direito, A., \& Mhurchu, C. N. (2013). Active Videogames and Weight Management: Is There a Future? Games Health J, 2(3), pp. 179-182. doi:10.1089/g4h.2013.0031

Markert, J., Herget, S., Petroff, D., Gausche, R., Grimm, A., Kiess, W., \& Bluher, S. (2014). Telephone-based adiposity prevention for families with overweight children (T.A.F.F.-Study): one year outcome of a randomized, controlled trial. Int J Environ Res Public Health, 11(10), pp. 10327-10344. doi:10.3390/ijerph111010327

McGowan, L., Cooke, L. J., Gardner, B., Beeken, R. J., Croker, H., \& Wardle, J. (2013). Healthy feeding habits: efficacy results from a cluster-randomized, controlled exploratory trial of a novel, habit-based intervention with parents. The American Journal of Clinical Nutrition, 98(3), pp. 769-777. doi:10.3945/ajcn.112.052159

McLean, N., Griffin, S., Toney, K., \& Hardeman, W. (2003). Family involvement in weight control, weight maintenance and weight-loss interventions: A systematic review of randomised trials. International Journal of Obesity, 27(9), pp. 987-1005.

Michie, S., Atkins, L. \& West, R. (2014). The Behaviour Change Wheel: A Guide to Designing Interventions UK: Silverback Publishing.

Mikkelsen, M. V., Husby, S., Skov, L. R., \& Perez-Cueto, F. J. A. (2014). A systematic review of types of healthy eating interventions in preschools. Nutrition Journal, 13doi:10.1186/1475-2891-13-56

Michie, S., Ashford, S., Sniehotta, F. F., Dombrowski, S. U., Bishop, A., \& French, D. P. (2011). A refined taxonomy of behaviour change techniques to help people change their physical activity and healthy eating behaviours: The CALO-RE taxonomy. Psychology \& Health, 26(11), pp. 1479-1498. doi:10.1080/08870446.2010.540664

Mitchell, G. L., Farrow, C. V., Haycraft, E., \& Meyer, C. (2013). Parental influences on children's eating behaviour and characteristics of successful parent-focussed interventions. Appetite, 60doi:10.1016/j.appet.2012.09.014 
Moher, D., Liberati, A., Tetzlaff, J., Altman, D. G., \& The, P. G. (2009). Preferred Reporting Items for Systematic Reviews and Meta-Analyses: The PRISMA Statement. PLoS Med, 6(7), p e1000097. doi:10.1371/journal.pmed.1000097

National Health Service. (2014). Eating a balanced diet. Retrieved Date from http://www.nhs.uk/Livewell/Goodfood/Pages/Healthyeating.aspx.

National Health Service. (2015). The eatwell plate. Retrieved Date from http://www.nhs.uk/Livewell/Goodfood/Pages/eatwell-plate.aspx.

National Health Service. (2017). Statistics on Obesity, Physical Activity and Diet. Retrieved Date from https://www.gov.uk/government/uploads/system/uploads/attachment_data/file/613532 /obes-phys-acti-diet-eng-2017-rep.pdf.

Nicklaus, S., Boggio, V., Chabanet, C., \& Issanchou, S. (2005). A prospective study of food variety seeking in childhood, adolescence and early adult life. Appetite, 44(3), pp. 289-297. doi:10.1016/j.appet.2005.01.006

Nyström, C. D., Sandin, S., Henriksson, P., Henriksson, H., Trolle-Lagerros, Y., Larsson, C., .. L Löf, M. (2017). Mobile-based intervention intended to stop obesity in preschoolaged children: the MINISTOP randomized controlled trial1,2. The American Journal of Clinical Nutrition, 105(6), pp. 1327-1335.

Ogden, J. (2012). Health Psychology New York, USA: McGraw-Hill.

Patrick, H., \& Nicklas, T. A. (2005). A review of family and social determinants of children's eating patterns and diet quality. J Am Coll Nutr, 24(2), pp. 83-92.

Pampel, F. C., Krueger, P. M., \& Denney, J. T. (2010). Socioeconomic Disparities in Health Behaviors. Annual review of sociology, 36, pp. 349-370. doi:10.1146/annurev.soc.012809.102529

Pearson, N., Atkin, A. J., Biddle, S. J., \& Gorely, T. (2010). A family-based intervention to increase fruit and vegetable consumption in adolescents: a pilot study. Public Health Nutr, 13(6), pp. 876-885. doi:10.1017/s1368980010000121 
Pearson, N., Ball, K., \& Crawford, D. (2012). Parental influences on adolescent fruit consumption: The role of adolescent self-efficacy. Health Education Research, 27(1), pp. 14-23.

Petty, R. E. B., P. (2012). The Elaboration Likelihood Model. In P. Van Lange, Kruglanksi, A., \& Higgins, E. (Ed.), The Handbook of Theories of Social Psychology (Vol. 1, pp. 224 - 242). London, UK: SAGE.

Poti, J. M., \& Popkin, B. M. (2011). Trends in energy intake among US children by eating location and food source, 1977-2006. J Am Diet Assoc, 111(8), pp. 1156-1164. doi:10.1016/j.jada.2011.05.007

Rasmussen, M., Krolner, R., Klepp, K. I., Lytle, L., Brug, J., Bere, E., \& Due, P. (2006). Determinants of fruit and vegetable consumption among children and adolescents: a review of the literature. Part I: Quantitative studies. Int J Behav Nutr Phys Act, 3, p 22. doi:10.1186/1479-5868-3-22

Rodd, C., \& Sharma, A. K. (2016). Recent trends in the prevalence of overweight and obesity among Canadian children. [10.1503/cmaj.150854]. Canadian Medical Association Journal, 188(13), p E313.

Rodearmel, S. J., Wyatt, H. R., Barry, M. J., Dong, F., Pan, D., Israel, R. G., . . Hill, J. O. (2006). A Family-Based Approach to Preventing Excessive Weight Gain. Obesity, 14(8), pp. 1392-1401.

Rudolf, M. (2012). Prevention of obesity through home visiting up to the age of 2 years: a promising but costly approach. BMJ, 344, p e3931. doi:10.1136/bmj.e3931

Savage, J. S., Fisher, J. O., \& Birch, L. L. (2007). Parental influence on eating behavior: conception to adolescence. J Law Med Ethics, 35(1), pp. 22-34. doi:10.1111/j.1748720X.2007.00111.x

Schmied, E., Parada, H., Horton, L., Ibarra, L., \& Ayala, G. (2015). A process evaluation of an efficacious family-based intervention to promote healthy eating: The Entre 
Familia: Reflejos de Salud study. Health Education \& Behavior, 42(5), pp. 583-592. doi: $10.1177 / 1090198115577375$

Scheiwe, A., Hardy, R. \& Watt, R.G. (2010). Four-year follow-up of a randomized controlled trial of a social support intervention on infant feeding practices. Maternal \& Child Nutrition, 6, pp. 328-337. doi: 10.1111/j.1740-9709.2009.00231

Sheeran, P., \& Webb, T. L. (2016). The Intention-Behavior Gap. Social and Personality Psychology Compass, 10(9), pp. 503-518. doi:doi:10.1111/spc3.12265

Shloim, N., Edelson, L. R., Martin, N., \& Hetherington, M. M. (2015). Parenting Styles, Feeding Styles, Feeding Practices, and Weight Status in 4-12 Year-Old Children: A Systematic Review of the Literature. Front Psychol, 6, p 1849. doi:10.3389/fpsyg.2015.01849

Simons, M., Brug, J., Chinapaw, M. J., de Boer, M., Seidell, J., \& de Vet, E. (2015). Replacing Non-Active Video Gaming by Active Video Gaming to Prevent Excessive Weight Gain in Adolescents. PLoS One, 10(7), p e0126023. doi:10.1371/journal.pone.0126023

Spence, C. (2017). Breakfast: The most important meal of the day? International Journal of Gastronomy and Food Science, 8, pp. 1-6. doi:https://doi.org/10.1016/j.ijgfs.2017.01.003

State of Obesity. (2017). The State of Childhood Obesity. Retrieved $2^{\text {nd }}$ February 2018 from https://stateofobesity.org/childhood-obesity-trends/

Subar, A. F., Freedman, L. S., Tooze, J. A., Kirkpatrick, S. I., Boushey, C., Neuhouser, M. L., . . Krebs-Smith, S. M. (2015). Addressing Current Criticism Regarding the Value of Self-Report Dietary Data. J Nutr, 145(12), pp. 2639-2645. doi:10.3945/jn.115.219634 
Sun, A., Cheng, J., Bui, Q., Liang, Y., Ng, T., \& Chen, J. L. (2017). Home-Based and Technology-Centered Childhood Obesity Prevention for Chinese Mothers With Preschool-Aged Children. J Transcult Nurs, p 1043659617719139. doi:10.1177/1043659617719139

Tabak, R. G., Tate, D. F., Stevens, J., Siega-Riz, A. M., \& Ward, D. S. (2012). Family Ties to Health program: A randomized intervention to improve vegetable intake in children. Journal of Nutrition Education and Behavior, 44(2), pp. 166-171.

Thompson, D., Bhatt, R., Lazarus, M., Cullen, K., Baranowski, J., \& Baranowski, T. (2012). A Serious Video Game to Increase Fruit and Vegetable Consumption Among Elementary Aged Youth (Squire's Quest! II): Rationale, Design, and Methods. JMIR Res Protoc, 1(2), p e19. doi:10.2196/resprot.2348

Thompson, D., Bhatt, R., Vazquez, I., Cullen, K. W., Baranowski, J., Baranowski, T., \& Liu, Y. (2015). Creating action plans in a serious video game increases and maintains child fruit-vegetable intake: a randomized controlled trial. International Journal of Behavioral Nutrition and Physical Activity, 12(1), p 39. doi:10.1186/s12966-0150199-z

USDA. (2018). Women, Infants and Children (WIC). Retrieved $2^{\text {nd }}$ February 2018 from https://www.fns.usda.gov/wic/women-infants-and-children-wic.

Van Lippevelde, W., Verloigne, M., De Bourdeaudhuij, I., Brug, J., Bjelland, M., Lien, N., \& Maes, L. (2012). Does parental involvement make a difference in school-based nutrition and physical activity interventions? A systematic review of randomized controlled trials. International Journal of Public Health, 57(4), pp. 673-678.

Virudachalam, S., Chung, P. J., Faerber, J. A., Pian, T. M., Thomas, K., \& Feudtner, C. (2016). Quantifying parental preferences for interventions designed to improve home 
food preparation and home food environments during early childhood. Appetite, 98, pp. 115-124.

Vitolo, M. R., Rauber, F., Campagnolo, P. D., Feldens, C. A., \& Hoffman, D. J. (2010). Maternal dietary counseling in the first year of life is associated with a higher healthy eating index in childhood. $J$ Nutr, 140(11), pp. 2002-2007. doi:10.3945/jn.110.125211

Vitolo, M. R., Bortolini, G. A., Campagnolo, P. D., \& Hoffman, D. J. (2012). Maternal dietary counseling reduces consumption of energy-dense foods among infants: a randomized controlled trial. J Nutr Educ Behav, 44(2), pp. 140-147. doi:10.1016/j.jneb.2011.06.012

Vivier, P. \& Tomkins, C. (2008) Health Consequences of Obesity in Children and Adolescents. In E. Jelalian \& R. Steele (Eds,)m Childhood and Adolescent Obesity (p.13). New York: SpringerWalker, J. L., Ardouin, S., \& Burrows, T. (2017). The validity of dietary assessment methods to accurately measure energy intake in children and adolescents who are overweight or obese: a systematic review. European Journal of Clinical Nutritiondoi:10.1038/s41430-017-0029-2

Wardle, J., Cooke, L. J., Gibson, E. L., Sapochnik, M., Sheiham, A., \& Lawson, M. (2003). Increasing children's acceptance of vegetables; a randomized trial of parent-led exposure. Appetite, 40(2), pp. 155-162.

Watt, R. G., Tull, K. I., Hardy, R., Wiggins, M., Kelly, Y., Molloy, B., . . McGlone, P. (2009). Effectiveness of a social support intervention on infant feeding practices: randomised controlled trial. J Epidemiol Community Health, 63(2), pp. 156-162. doi:10.1136/jech.2008.077115

Wen, L. M., Baur, L. A., Rissel, C., Flood, V., Simpson, J. M., Hayes, A., . . Wardle, K. (2012). Healthy Beginnings Trial Phase 2 study: follow-up and cost-effectiveness analysis. J Obes, 33(2), pp. 396-401. doi:10.1155/2014/476230 
Wen, L. M., Baur, L. A., Simpson, J. M., Rissel, C., Wardle, K., \& Flood, V. M. (2012). Effectiveness of home based early intervention on children's BMI at age 2: randomised controlled trial. Bmj, 344, p e3732. doi:10.1136/bmj.e3732

Wen, L., Baur, L. A., Simpson, J. M., \& et al. (2015). Sustainability of effects of an early childhood obesity prevention trial over time: A further 3-year follow-up of the healthy beginnings trial. JAMA Pediatrics, 169(6), pp. 543-551. doi:10.1001/jamapediatrics.2015.0258

Wieland, M. L., Hanza, M. M. M., Weis, J. A., Meiers, S. J., Patten, C. A., Clark, M. M., . . . Sia, I. G. (2017). Healthy Immigrant Families: Randomized Controlled Trial of a Family-Based Nutrition and Physical Activity Intervention. Am J Health Promot, 32(2), pp. 473-484. doi:10.1177/0890117117733342

Wolfenden, L., Wyse, R. J., Britton, B. I., Campbell, K. J., Hodder, R. K., Stacey, F. G., . . . James, E. L. (2012). Interventions for increasing fruit and vegetable consumption in children aged 5 years and under. Cochrane Database Syst Rev, 11, p CD008552. doi:10.1002/14651858.CD008552.pub2

Wolfenden, L., Wyse, R., Campbell, E., Brennan, L., Campbell, K. J., Fletcher, A., . . . Heard, T. R. (2014). Randomized controlled trial of a telephone-based intervention for child fruit and vegetable intake: long-term follow-up. Am J Clin Nutr, 99(3), pp. 543-550. doi:10.3945/ajcn.113.071738

World Health Organisation. (2015). Healthy Diet. Retrieved $2^{\text {nd }}$ February 2018 from http://www.who.int/mediacentre/factsheets/fs394/en/.

World Health Organisation. (2017). mHealth: New horizons through mobile technologies. Retrieved Date from http://www.who.int/goe/publications/goe_mhealth_web.pdf. 
Wrieden, W. L., \& Levy, L. B. (2016). 'Change4Life Smart Swaps': quasi-experimental evaluation of a natural experiment. Public Health Nutrition, 19(13), pp. 2388-2392. doi:10.1017/S1368980016000513

Wyse, R., Campbell, K. J., Brennan, L., \& Wolfenden, L. (2014). A cluster randomised controlled trial of a telephone-based intervention targeting the home food environment of preschoolers (The Healthy Habits Trial): the effect on parent fruit and vegetable consumption. Int J Behav Nutr Phys Act, 11, p 144. doi:10.1186/s12966014-0144-6

Wyse, R., Wolfenden, L., \& Bisquera, A. (2015). Characteristics of the home food environment that mediate immediate and sustained increases in child fruit and vegetable consumption: Mediation analysis from the Healthy Habits cluster randomised controlled trial. The International Journal of Behavioral Nutrition and Physical Activity, 12, p 118.

Wyse, R., Wolfenden, L., Campbell, E., Campbell, K. J., Wiggers, J., Brennan, L., . . Heard, T. R. (2012). A cluster randomized controlled trial of a telephone-based parent intervention to increase preschoolers' fruit and vegetable consumption. Am J Clin Nutr, 96(1), pp. 102-110. doi:10.3945/ajen.111.030585

Wyse, R. J., Wolfenden, L., Campbell, E., Brennan, L., Campbell, K. J., Fletcher, A., . . Wiggers, J. (2010). A cluster randomised trial of a telephone-based intervention for parents to increase fruit and vegetable consumption in their 3- to 5-year-old children: study protocol. BMC Public Health, 10, p 216. doi:10.1186/1471-2458-10-216

Zajonc, R. (1968). Attitudinal effects of mere exposure. J Pers Soc Psychol(9), pp. 1-27. 